
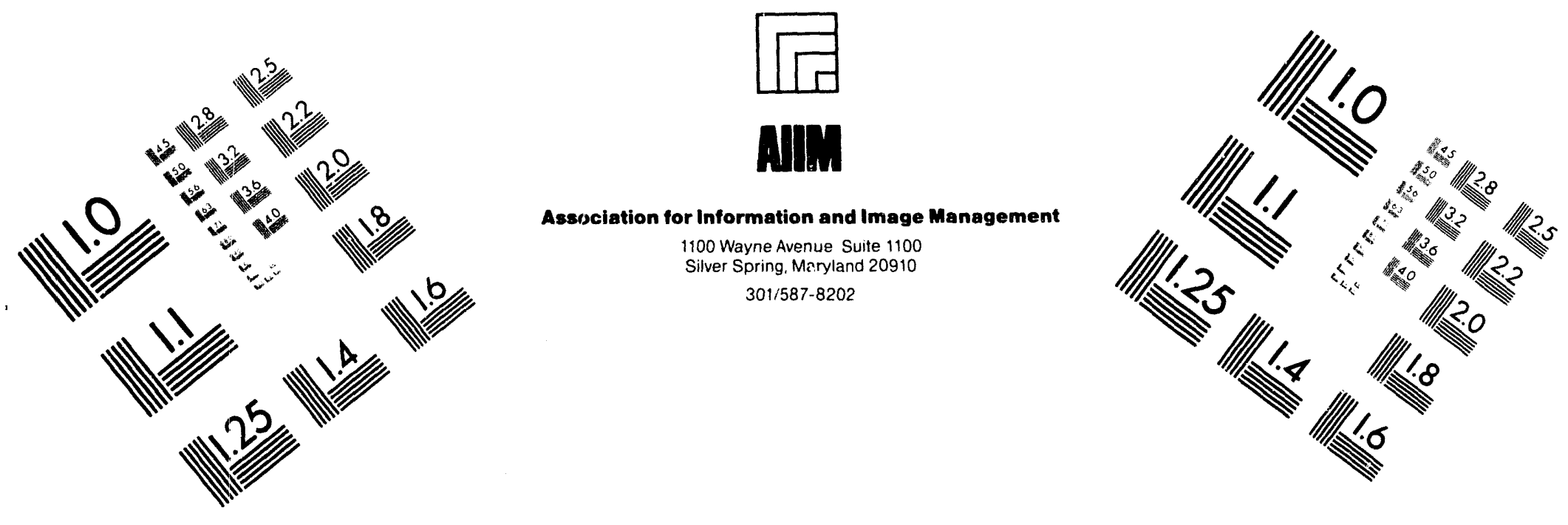

\title{
Centimeter
}

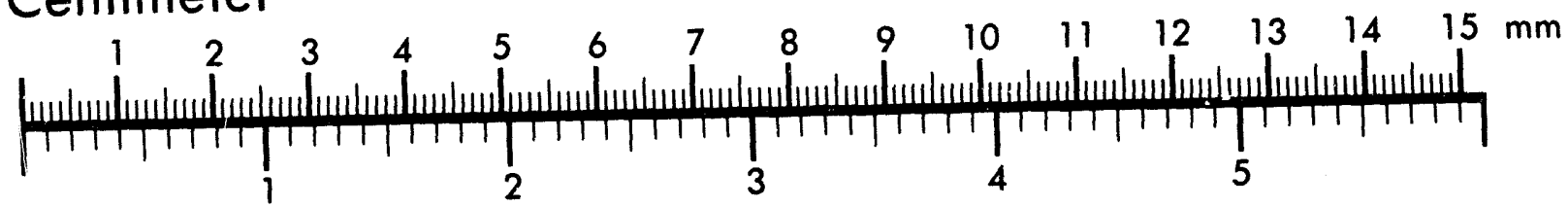
Inches
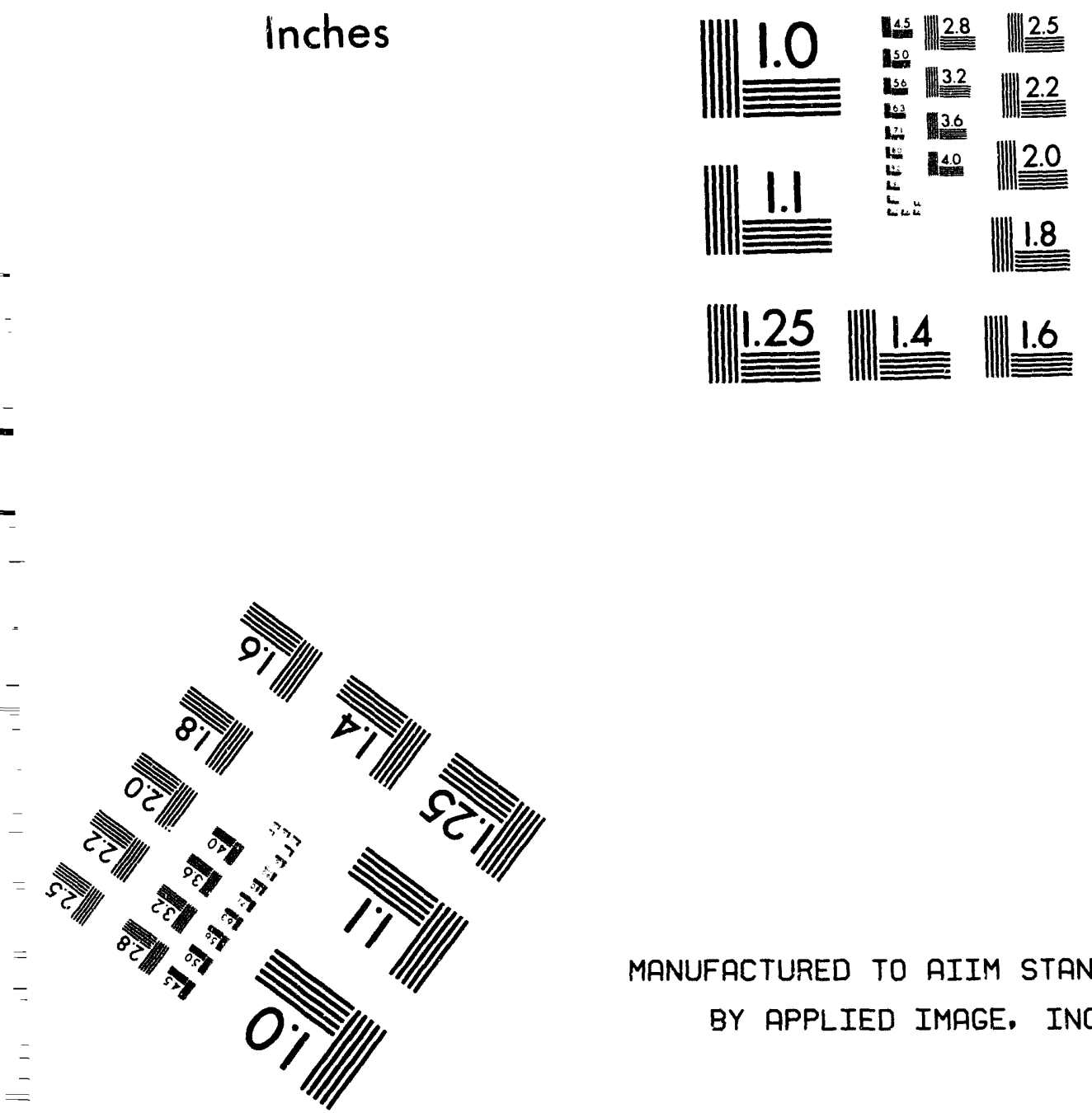

MANUFACTURED TO AIIM STANDARDS BY APPLIED IMAGE. INC.

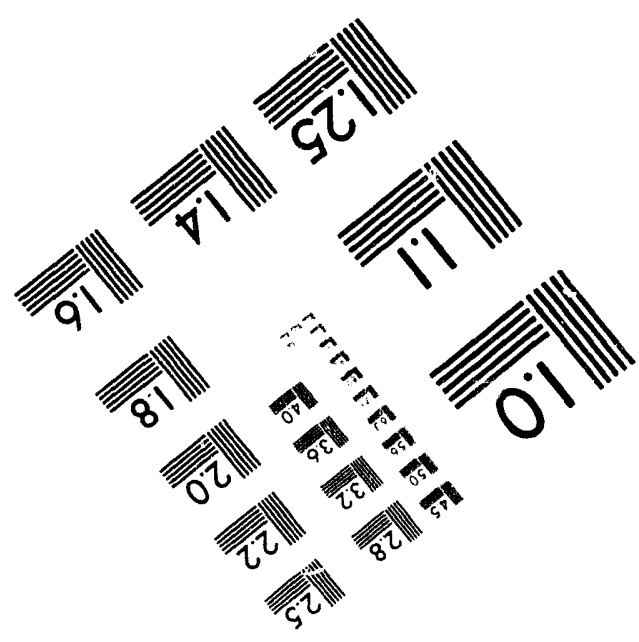



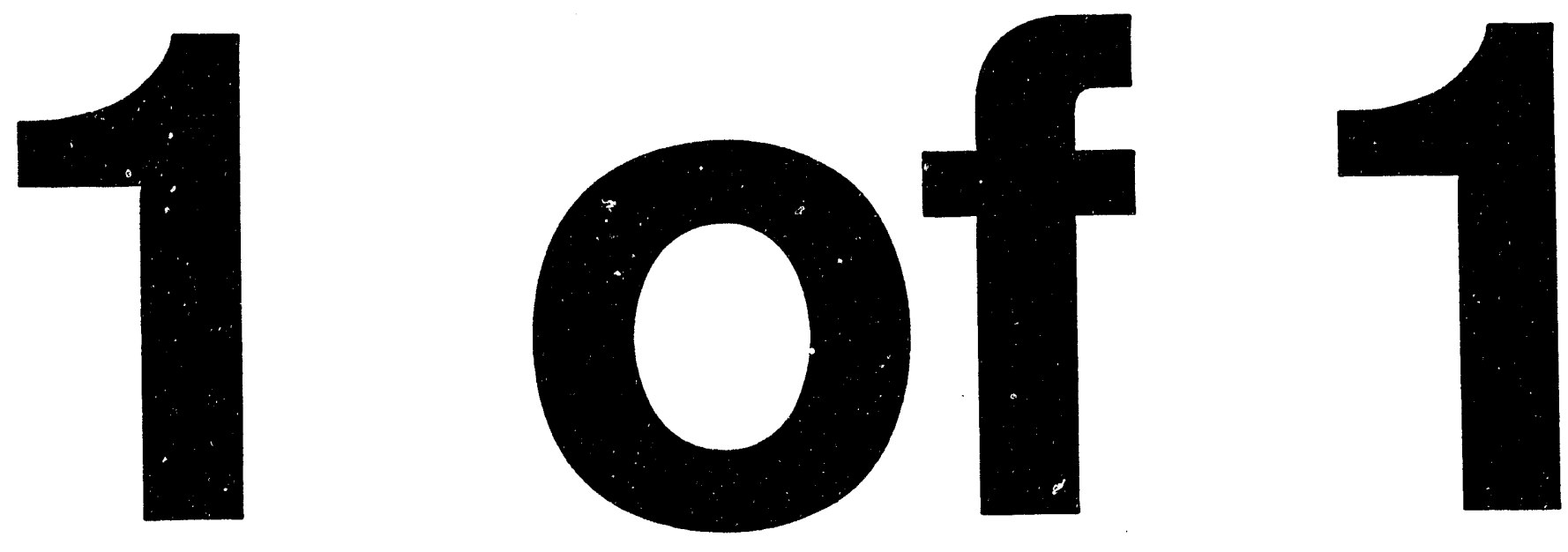


\section{TRANSURANIC WASTE PROJECTIONS AT SRS FOR LONG RANGE PLANNING (U)}

H. E. HOOTMAN $A 2 A$

J. R. COOK

APPROVED BY:

T. H. GOULD, MANAGER

STRATEGIC PLANNING AND ANALYSIS

MAY 1994

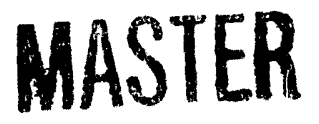

Westinghouse Savannah River Company Savannah River Site Aiken, SC 29808

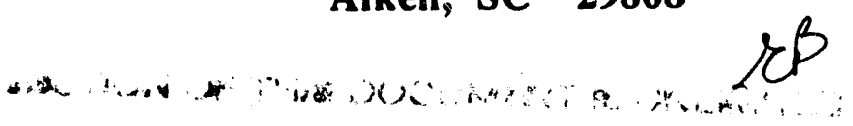




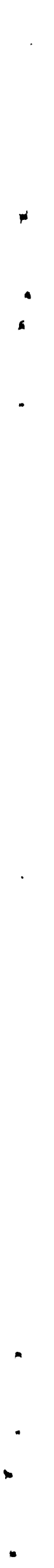




\section{CONHWNIS}

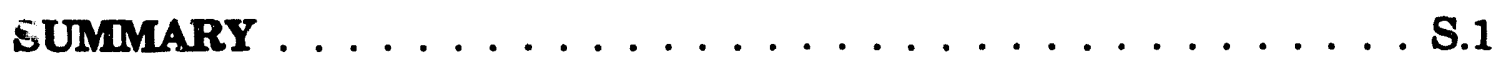

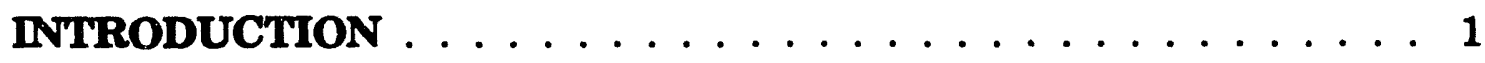

DISCUSSION. ....................... 1

Background. ..................... 1

Waste Generation Based on Past D\&D Projects . . . . . . . . 2

TRU Waste Generation Projection Assumptions. . . . . . . . . 3

Facility D\&D Sequence and Waste Generation . . . . . . . . . 4

Analysis of the Current TRU Waste Holdings . . . . . . . . 6

Combining Current and Projected TRU Waste Holdings. . . . . 7

Accuracy of the Scoping Study . . . . . . . . . . . . 8

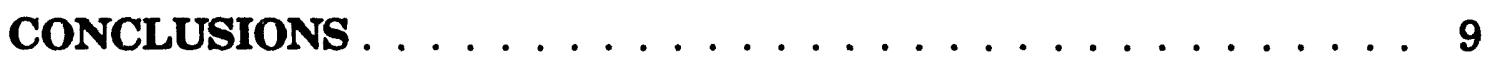

REFERENCES ........................ 10

APPENDIX (Available as a separate document,WSRC-RP-94-451 Appendix)

TRU Category Summary . . . . . . . . . . . . . . . A2

Culvert Category Summary . . . . . . . . . . . . A3

Non-Culvert Category Summary . . . . . . . . . . . . A4

COBRA Data Used in the Analysis

A5. Pu-238 TRU Culvert

A9. Pu-238 TRU Non-Culvert

A12. Pu-238 TRU Concrete Pours

A13. Pu-239 TRU Culvert

A17. Pu-239 TRU Non-Culvert

A20. Pu-239 TRU Concrete Pours

A21. Np-237 TRU Culvert

A22. Np-237 TRU Non-Culvert

A24. Np-237 TRU Concrete Pours

A25. Am-241 TRU

A27. $\mathrm{Cm}-244$ TRU

A29. Cf-252 TRU 


\section{LISTOFTABLES}

Table 1. Alpha Waste Categories. . . . . . . . . . . . . . . . 11

Table 2. Alpha Waste in FY 2023. . . . . . . . . . . . . . . 12

Table 3. Definition of Alpha Waste Categories . . . . . . . . . . . 13

Table 4. History of Culvert TRU Waste Receipts . . . . . . . . . . . 14

Table 5. History of Non-Culvert TRU Waste Receipts . . . . . . . . . 14

Table 6. HB-Line D\&D Waste Generation Data. . . . . . . . . . . . 15

Table 7. FB-Line D\&D Waste Generation Data . . . . . . . . . . 16

Table 8. Definition of D\&D Critical Planning Parameters . . . . . . 17

Table 9. Projected Total Alpha Waste Receipts. . . . . . . . . . . . . 19

Table 10. Projected Culvert TRU Waste Receipts . . . . . . . . . . . 20

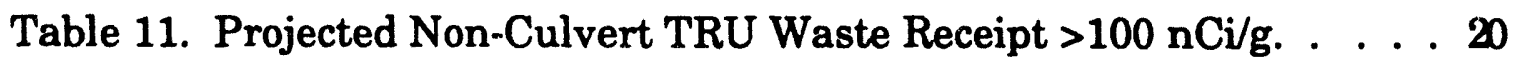

Table 12. Projected Non-Culvert TRU Waste Receipt 10 to $100 \mathrm{nCi} / \mathrm{g}$. . 21

Table 13. Projected Non-Culvert TRU Waste Receipt $<10 \mathrm{nCi} / \mathrm{g} . \ldots . .21$

Table 14. Disposition of Current Retrievable Waste. . . . . . . . . 22

\section{LST OF EIGURES}

Figure 1. Current Transuranic Solid Waste Holdings Disposition. . . 24

Figure 2. Projected Annual Alpha Waste. . . . . . . . . . . . 25

Figure 3. Current Retrievable TRU Waste Decay . . . . . . . . . . 26 
Transuranic Waste Projections for Long Range Planning

\section{SUMMMARY}

This report predicts 30 year receipts of solid transuranic (TRU) wastes from eventual plutonium facility deactivation and cleanup, and combines them with the existing TRU waste holdings to provide a technical and quantitative basis for interim and long range TRU waste management planning.

The current TRU waste holdings have been characterized based on data from the Computerized Radioactive Waste Burial Records Analysis (COBRA) system. Six TRU waste disposition categories have been identified for existing TRU waste as shown in Table 1. An additional category has been quantified that includes projected waste volumes from the Decontamination and Decommissioning (D\&D) of TRU waste generating facilities. These projections are based on COBRA data from D\&D of the original plutonium finishing facilities in $\mathrm{F}$ and $\mathrm{H}$ Areas that were replaced in the 1970's and 80's.

The predominant sources of TRU solid wastes at SRS are the plutonium contaminated processing and laboratory facilities. The projected waste volumes shown in Table 1 more than doubles the current TRU waste holdings and results in over one million cubic feet of retrievably stored TRU waste. The projected waste quantities indicate the need for an additional 6 TRU storage pads for low activity waste if only waste greater than $100 \mathrm{nCi} / \mathrm{g}$ is stored on pads. If waste greater than $10 \mathrm{nCi} / \mathrm{g}$ is stored on pads, an additional 11 pads will be needed. Space for about 282 culverts of high activity waste will also be needed. This additional storage will be needed if offsite shipments to a national repository do not begin befcre completion of plutonium facility D\&D.

Total projected TRU wastes in the year 2023 are shown in Table 2 assuming current retrievable waste distributions. TRU waste volume projections are considered important in long range planning because DOE strategy is to transport this waste to a national repository. After offsite shipment of repository qualified TRU waste, about 70 percent of the TRU waste volume and activity will remain onsite. Therefore, a more durable long term storage mode should be considered for the pad stored waste that will remain at SRS. Figure 3 shows that the radioactivity of the current retrievably stored TRU waste holdings will decay by 98 percent to a residual 10,000 Curie level, predominantly $\mathrm{Pu}-239$, in a thousand years. Planned shipment of the Pu-239 TRU wastes to an offsite national repository will further reduce the residual level by a factor of 20 .

All COBRA data used in this alpha waste analysis is available in a separate Appendix. 
This page is intentionally left blank. 
Transuranic Waste Projections for Long Range Planning

WSRC-RP-94-451

\section{INTRODUCTION}

The mission emphasis at SRS has changed from production to managing inventories of nuclear materials, disposing of nuclear wastes, and stabilizing and deactivating surplus production facilities. Uncertainties exist in the timing, extent of stabilization, and D\&D required for the contaminated production facilities. Detailed analyses of the risk, costs, and engineering feasibility are needed to define production facility end states to ensure expected reduction in health and environmental risk. In the meantime, scoping projections are required to satisfy DOE requirements for 30 year plans, and to indicate where detailed analysis should be funded.

\section{DISCUSSION}

\section{Background}

The methodology used in this study for projecting future TRU waste generation used past experience and current DOE programmatic guidance as a basis for predicting future waste generation. SRS has several facilities that generate TRU waste as a result of processing, storage, analytical work, and R\&D. Plutonium processing facilities (221-FB-Line and 221-HB-Line) are located on the roof of each of the two canyon buildings. A separate facility (Building 235-F) is located outside the 221-F canyon and was used to process Pu-238 and Np-237. Both of the laboratories (772-F and 773-A) generate low amounts of TRU waste. There are also plans for the SED Facility in 773-A to undergo D\&D in the near future. These facilities are highly contaminated with plutonium which is extremely toxic when inhaled. For personnel protection, processing takes place inside gloveboxes or cabinets with controlled ventilation. Containment and ventilation must be maintained to avoid plutonium release. These facilities have generated all of the TRU waste in current retrievable storage and will be the major source of future TRU waste. Total dismantlement of these plutonium facilities will probably be required within the next two decades.

Facility deactivation or decommissioning can be considered to be made up of five different stages: shutdown, stabilization, decontamination, dismantling and disposal. Between facility stabilization and decontamination and dismantling stages, a facility can undergo an indefinite period of surveillance and maintenance (S\&M) depending on the assessment of risk and cost for further action. A lengthy S\&M period for these plutonium facilities after shutdown could involve relatively high risks and costs. Experience has shown that the cabinet/hood interiors cannot be 


\section{Transuranic Waste Projections for Long Range Planning}

adequately decontaminated to reduce risk to acceptable levels. For these reasons, the D\&D of these facilities should be of the highest priority at SRS. Previous D\&D of similar facilities at SRS has demonstrated effective methods of performing the work and has resulted in the development and applicatior of practical technology and equipment (Reference 2). Total dismantlement of the plutonium facilities will probably be required.

Tables 4 and 5 show past TRU waste volume generation as a function of source facility for high activity culvert stored waste ( $>0.5$ Curie per drum) and low activity non-culvert stored waste ( $<0.5$ Curie per drum). The predominant sources of TRU solid wastes at SRS can be seen to be the plutonium contaminated processing and laboratory facilities.

\section{Waste Generation Predictions Based on Past D\&D Projects}

The strategy of this study is to use past experience as a basis for predicting future waste generation. Three types of solid waste are generated in the D\&D of plutonium facilities: TRU waste containing transuranic isotopes of greater than 20 year half-life at concentrations more than 100 nanocuries per gram ( $\mathrm{nCi} / \mathrm{g}$ ) alpha, low level waste (LLW) containing less than 10 $\mathrm{nCi} / \mathrm{g}$ alpha, and mixed waste that may be either TRU or LLW combined with a hazardous material. In this analysis, attention is limited to the alpha waste. LLW is not subject to off-site shipment as is the case with alpha bearing wastes. Projected waste volumes and activities used in this analysis are based on the experience gained in previous dismantlement and decontamination projects.

\section{Old 221-HB-Line D\&D Experience}

The old HB-Line operated from 1963 to 1984 producing radioisotopic heat source Plutonium-238 material for NASA programs. The facility cleanup effort was begun in 1984 and has continued intermittently to today. Approximately 108,000 cubic feet of solid TRU waste was generated for the 5,000 square feet of facility cleaned thus far or about 21 cubic feet of waste per square foot of empty facility floor area. This basis was cho: en because most plutonium facilities require a comparable operating and maintenance area to support the enclosed processes. About half of the solid waste generated was transuranic (TRU) waste, an equal amount of low level waste (LLW) $v$ as also generated. Although the elapsed time for the cleanup has been 9 years, the effort was intermittent, and it is estimated it would have required the equivalent of about 5 years of continuous effort. It is estimated that 3 more years will be required to complete $D \& D$ of the facility. Records of the 
Transuranic Waste Projections for Long Range Planning

amount of liquid decontamination waste generated to date are unavailable. The contaminated wash water was pumped to the adjacent canyon for evaporation and transfer to the area waste tanks. This information is now being documented for future reference. Table 6 itemizes TRU solid waste receipts from the COBRA data. Total retrievable TRU (Pu-238) waste volume is the sum of culvert and non-culvert wastes.

Old 221-FB-Line Experience

The old FB-Line facility, operated from 1959 to 1968 , consisted of processing equipment located in gloveboxes on the third level of the 221-F Canyon facility. This facility was dismantled and decontaminated from about 1972 to 1976. Approximately 97,151 cubic feet of solid TRU waste was generated from cleanup of the 7,500 sq. $\mathrm{ft}$. facility or about 13 cubic feet of waste per square foot of empty facility floor area. Table 7 itemizes TRU waste receipts from the COBRA data from the old 221-FB-Line cleanup. Total retrievable TRU (Pu-239) waste volume is the sum of culvert, non-culvert, concrete pours, and low level alpha (LLA) wastes. Pours and LLA waste volumes were considered to be non-culvert waste by current definition.

\section{TRU Waste Generation Projection Assumptions}

A previous study in 1986 (Reference 3) attempted to estimate D\&D waste generation by estimation by knowledgeable peer teams, but their estimates of 20,000 cubic feet of TRU waste generation for each of the HB and FB Lines appears a factor of five low compared to COBRA data. Projected waste volumes in this analysis are based on data shown in Table 8 . The methodology proposed derives TRU waste volume from estimation of contaminated facility floor area multiplied by waste generation factors, 13 or 21 cubic feet of waste generated per square foot of contaminated floor area for $\mathrm{Pu}-238$ or $\mathrm{Pu}-239$ facilities respectively. The different factors for $\mathrm{Pu}-238$ and $\mathrm{Pu}-239$ facilities is due to the higher specific activity of $\mathrm{Pu}-238$. The waste was further classified as culvert and non-culvert since the data indicates about 4 percent of the waste generated is culvert waste. Finally, the waste radioactivity in Curies can be estimated by multiplying the waste volume by

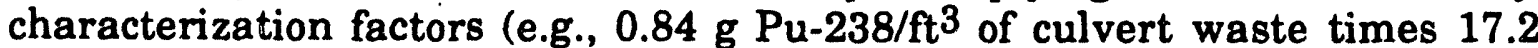
Curies per gram of $\mathrm{Pu}-238$ ).

Current DOE plans forecast completion of the deinventory and flushing operations in F and H Canyons by FY 1996 and FY 2000, respectively. It is assumed that deactivation and stabilization of plutonium operations starts in 2000 and extends for 5 years. Cleanout and deinventory of 221-FB-Line, 
Transuranic Waste Projections for Long Range Planning

221-HB-Line, and 235-F is assumed except for vault storage until the new Complex 21 vault is in operation in 2005. Upon completion of the new Complex 21 vault, around 2005-2010, the remaining unirradiated nuclear materials will be stabilized and repackaged for shipment and/or stabilized for disposal, depending upon economic value and evolving criteria. TRU wastes generated in 772-F are associated with continuing analysis of Environmental Remediation characterization samples.

\section{Facility D\&D Sequence and Waste Generation}

The D\&D sequence of plutonium contaminated facilities is assumed to utilize a common source group of work crews and are scheduled in the following semi-succession. If funding and manpower are available, several facilities may undergo D\&D simultaneously. However, the same amount of waste is anticipated in either case.

Old HB-Line will complete present D\&D in 1994-96

Approximately $3400 \mathrm{sq}$. $\mathrm{ft}$. of contaminated facility area remains to be cleaned out. Using the generation factor of 21 for Pu-238 facilities from Table 8 yields approximately 72,000 cubic feet of TRU waste. Four percent of the TRU waste (from Table 8) will be stored in culverts, about 2900 cubic feet, with an activity of 81,000 Curies. The 69,000 cubic feet remainder will contain 6,000 Curies to be stored in drums or boxes on the storage pads. It is assumed about three years are required to complete D\&D of the facility.

SED in 773-A will undergo D\&D in 1995-8

This experimental facility at SRTC is a high priority candidate for complete D\&D because it is situated near the site boundary and will be transitioned to EM-40. The floor area of SED is about 3000 square feet. Approximately 40,000 cubic feet of TRU waste are estimated to be generated using the waste generation factor of 13 for Pu-239 waste from Table 8. Four percent of the TRU waste will be stored in culverts, the remainder is non-culvert waste to be stored in drums or boxes. It is assumed about four years will be required to complete D\&D of the facility, therefore, $400 \mathrm{ft}^{3}$ of culvert waste and $9600 \mathrm{ft}^{3}$ of non-culvert waste are shown under 773-A on Tables 10 through 13 respectively. 
Transuranic Waste Projections for Long Range Planning

WSRC-RP-94-451

235-F PUFF and Thoria Line will undergo D\&D in 1996-2003

The PUFF facility operated from 1978 to 1986 providing $\mathrm{Pu}-238$ heat source fuel forms for NASA programs. The facility first fioor contaminated area is 5,200 sq. $\mathrm{ft}$.. The Thoria Line that produced oxide billets for extrusion of $\mathrm{Pu}$ 238 target assemblies is about 1500 square feet. Using the waste generation factor of 21 for Pu-238 facilities, about 140,000 cubic feet of TRU waste will be generated cleaning up these facilities. Four percent of the TRU waste will be stored in culverts, the remainder is non-culvert waste stored in drums or boxes. It is assumed about seven years are required to complete D\&D of these two facilities

\section{1-HB-Line will undergo D\&D in 2003-2010}

The new HB-Line is located atop the H-Canyon building. This facility has just begun to operate this year. This HB-Line is used to convert neptunium and plutonium to oxide forms after passing through ion exchange columns. Assuming about 6700 square feet of contaminated area, approximately 140,000 cubic feet of TRU waste will be generated using the $\mathrm{Pu}-238$ waste generation factor of $21 \mathrm{ft}^{3}$ of waste per $\mathrm{ft}^{2}$ of contaminated floor area. Four percent of the TRU waste will be stored in culverts, the $r$ remainder is non-culvert waste stored in drums or boxes. It is assumed about seven years are required to complete D\&D of the facility. Operational wastes are estimated in the period prior to D\&D.

\section{FB-Line will undergo D\&D in 2010-2017}

This facility is designed to process low concentration plutonium solution from the canyon into plutonium metal or oxide. Extensive restoration of the new FB-Line facility has been in progress for the last decade. Assuming 7800 square feet of contaminated area, approximately 100,000 cubic feet of TRU waste will be generated using the generation factor of $13 \mathrm{ft}^{3}$ of waste per $\mathrm{ft}^{2}$ contaminated floor area for Pu-239 facilities. Four percent of the TRU waste will be stored in culverts, the remainder is non-culvert waste stored in drums or boxes. It is assumed about seven years are required to complete D\&D of the facility. Operational wastes are estimated in the period prior to D\&D.

The New Special Recovery (NSR), a new facility located in a hardened structure adjacent to FB-Line, is the replacement for FB-Line special recovery portion of the FB-Line. Due to mission changes, startup activities in the new facility were halted. NSR is currently maintained in a 
Transuranic Waste Projections for Long Range Planning

contamination free standby condition. No D\&D of this facility is necessary.

\section{Miscellaneous Facilities}

Plutonium storage vaults and analytical laboratories will be operated continuously during the future projection period. Plutonium is stored in two vaults within FB-Line and three vaults in Building 235-F. Two additional F-Area vaults (PSF and 247-F) could be started up over the next two years for materials storage. The Plutonium Storage Facility (PSF) is a new partially automated stacker retrieval vault cspable of storing plutonium bearing materials in shipping containers. This facility has a wide range of nondestructive assay equipment for confirmatory and accountability measurements of feed materials as wel: as advanced accountability features. At present, there are no current plans for startup PSF.

An allowance was assumed for TRU waste generation for vault storage activities that is related to continual assay and isotopic quality tracking. Laboratory waste generation (772-F \& 773-A) indicated in Figure 2 and Table 9 is related to restoration and remediation sample analyses. The Building 247-F vault and 221-HB-Line may provide additional plutonium storage capability where shipping containers will be stored manually. The plutonium stored in these separate vaults may be consolidated in a new Complex 21 vault during the period 2005-2010.

The method used to calculate the projected waste activities was to total the waste generation volumes in $\mathrm{Pu}-238$ and $\mathrm{Pu}-239$ facilities separately, use the appropriate multipliers, and combine the results. The operational wastes were assumed to be essentially the same as the predominant D\&D wastes with the exception that $10 \%$ was assumed to be the culvert waste fraction, otherwise characterization factors given in Table 8 were used.

\section{Analysis of the Current TRU Waste Holdings}

The current TRU waste holdings were characterized from COBRA data. Computer printouts were obtained for waste receipts from all TRU generating facilities since 1964 for culvert stored waste and since 1974 for pad stored TRU wastes. The information included in this analysis represents all of the current retrievably stored TRU waste up until mid CY 1992. 
In 1974, when retrievable transuranic waste pad storage was initiated, alpha waste greater than 10 nanocuries per gram was considered TRU waste. In about 1984, the lower limit defining TRU waste was changed to greater than 100 nanocuries per gram. Therefore, retrievably stored TRU waste falls into three different categories: less tha $10 \mathrm{nCi} / \mathrm{g}$, between 10 and $100 \mathrm{nCi} / \mathrm{g}$, and greater than $100 \mathrm{nCi} / \mathrm{g}$.

Long before retrievable storage, in 1959, alpha waste greater than 0.1 Curie per package at SRS was stored in concrete culverts. Later, a comparable definition of high activity alpha waste of 0.5 Curie per drum was established to differentiate high level activity alpha waste storage that required secondary containment by concrete culverts. Low activity alpha waste storage was in earthen trenches until 1974 when these wastes were pad stored in drum or boxes.

Figure 1 shows the current TRU Solid Waste Strategy (Reference 1) that defines the conceptual TRU waste processing facilities and waste streams. Table 14 quantifies the current TRU waste holdings feeds and outputs to the planned low and high activity transuranic waste facilities that will condition the waste for transfer to a national transuranic waste repository. Further analysis of the COBRA data was required to define the components of the different waste streams. First, the data was sorted by isotope, activity and container type. The gram quantities were converted to Curies of activity at the time that the waste was received, and then decayed to the year 1994. Future decay was also calculated $30,100,500$ and 1000 years into the future to allow assessment of future waste holdings activity in Figure 3. Curie values used in the calculation of $\mathrm{nCi} / \mathrm{g}$ and $\mathrm{Ci} / \mathrm{ft}^{3}$ for waste stream segregation are for CY 1994. A nominal waste density of 7 pounds per cubic foot of waste was used to convert waste volume to weight. All COBRA data used in this analysis is included in a separate Appendix.

\section{Combined Current and Projected TRU Waste Holdings}

Table 1 summarizes the current and projected TRU waste disposition categories derived from past and present definitions of transuranic waste. It appears that these waste streams can be can be more effectively allocated into seven waste disposition categories that are described in Table 3.

Projected TRU wastes up until the end of the 30 year planning period ending CY 2022 are shown in Figure 2 and Table 9. Tables 10 to 13 show projected waste volumes assuming the same distribution of activities as the current wastes and no offsite shipment of TRU waste in the interim. Table 10 shows 
projected culvert stored high activity ( $>0.5$ Curie per drum) TRU waste volume predictions as a function of source facility. Projected culvert waste volumes show only a 28 percent increase over the current culvert stored wastes shown in Table 4. The reason for the smaller growth of the high activity waste is that operating processes generate more high activity waste than do cleanout and D\&D activities.

Tables 11,12 and 13 show low activity ( $<0.5$ Curie per drum) TRU waste volume predictions as a function of source facility. Comparison of the projected non-culvert waste volumes to the presen non-culvert waste holdings shows a 237 percent increase in the alpha waste. The increase is due to the increase in job control waste from D\&D.

The volume distribution of the activity in culvert and non-culvert projected wastes was treated independently, but was assumed to be the same as the current waste holdings volume distributions. Table 2 shows the effect of the redistributed projected waste as a hypothetical alpha waste holdings in 2023. Therefore, the total SRS waste that can be sent to the Waste Isolation Pilot Plant (WIPP) under the current waste acceptance criteria without extensive rework is Category 1 which constitutes $27 \%$ of the volume and $25 \%$ of the activity of all the alpha waste stored in E-Area.

The projected holdings indicates the need for about 282 culverts (Table 10), and an additional 6 TRU storage pads (for non-culvert storage greater than $100 \mathrm{nCi} / \mathrm{g}$ in Table 11). If wastes greater than $10 \mathrm{nCi} / \mathrm{g}$ are placed on the TRU pads, 11 pads will be required instead of 6 pads (Table 12). These estimates assume offsite shipments to a national repository do not begin before completion of plutonium facility $D \& D$. These requirements were calculated by assuming all of the culvert waste is in equivalent drums of 7 cubic foot volume. A culvert will hold 14 drums, and a pad will hold about 3456 drums (triple stacked with provision for aisles). Even after offsite shipment, about 73 percent of the TRU waste volume and $75 \%$ of the activity will remain onsite.

\section{Accuracy of the Scoping Study}

The COBRA data was analyzed on the basis of annual receipts from the TRU waste generating facilities. This expedient was employed because the data was hand transferred by the author and thousands of entries would be involved in separate item receipt. The use of annual waste receipt summaries instead of individual container receipt data tends to allow more marginal culvert waste to meet the WIPP waste acceptance criteria, 
Transuranic Waste Projections for Long Range Planning

WSRC-RP-94-451

however, it also tends to increase the marginal non-culvert waste fraction that is less than $100 \mathrm{nCi} / \mathrm{g}$ and remains at SRS. A review of the data in the Appendix will show few entries that are marginal.

The activities of the $\mathrm{Pu}-238$ wastes may be $10-20$ percent high because the isotopic contents of the wastes are variable, aid a half-life of 87.7 years and a specific activity of $17.2 \mathrm{Ci} / \mathrm{g}$ for pure $\mathrm{Pu}-238$ was assumed. The activities of the $\mathrm{Pu}-239$ wastes may be $2-6$ percent low because the isotopic contents of the wastes are variable, and a half-life of 24,100 years and a specific activity of $0.0623 \mathrm{Ci} / \mathrm{g}$ for pure Pu-239 was assumed.

\section{CONCLUSTONS}

This scoping study is a further step in the continuing process of characterizing current and future TRU waste holdings. Reference 4 was an early attempt to characterize and document TRU waste retrievably stored in E-Area. This current study supplements that information, and effectively brings the previous study up to date.

The predicted TRU waste generation volume indicates that about 6 additional TRU storage pads will be required to store non-culvert waste greater than $100 \mathrm{nCi} / \mathrm{g}$ and 11 storage pads will be required to store nonculvert waste greater than $10 \mathrm{nCi} / \mathrm{g}$. About 282 culverts will be needed for future high activity waste storage with the necessary pad space. This waste characterization is also necessary input for conceptual design of any waste future waste processing facility. Several of the waste disposition categories (Categories $1,3,4, \& 5$ in Table 3) need further consideration and definition of long term treatment, storage and disposal (TSD) alternatives. Since low level alpha waste is to be placed in low level beta-gamma waste vaults, it appears to be more protected in the long term than the much higher activity pad-stored wastes.

The total SRS waste that can be sent to WIPP under the current waste acceptance criteria without extensive rework in Category 1 is about $27 \%$. Since $73 \%$ of the volume and activity remain at SRS, one may ask what is the point of sending TRU waste to WIPP? Figure 3 shows that after 500 years decay, the Pu-239 activity dominates the residual activity. The WIPP shipments will reduce the residual activity from the current $\mathrm{Pu}-239$ holdings from about 10,000 to 500 Curies or a factor of 20 . The lower residual activity in the retrievable TRU waste is comparable to the decayed residual activity in the non-retrievable TRU waste in the old burial ground. 
Transuranic Waste Projections for Long Range Planning

The results of this scoping study can be used in the Preliminary Environmental Impact Study for Waste Management. The results shown in Tables 10-13 might also be used by the Interim Solid Waste Task Team. The mission of this team is to prepare a plan for interim storage of TRU and mixed-TRU wastes on the E-Area storage pads and those being generated in the next decade. Waste stored since 1974 on surface storage pads are approaching their planned 20-year storage design limit. Corrosion is suspected on drums in sod covered pads, and water inleakage is suspected in drums on uncovered pads. The Interim Solid Waste Task Team is cilarged with defining storage options for safe and compliant storage of pad stored TRU wastes for the next decade.

\section{REFERENCES}

1. WSRC-RP-93-1448, Solid Waste Management Plan (U), Predecisional Draft, Revision 0, November 30, 1993.

2. R. H. Smith and H. E. Hootman, "Dismantlement and Decontamination of a Plutonium-238 Facility at SRS (U)", WSRC-RP-93-1376, January 1994.

3. W. P. Martin, "SRP Decontamination and Decommissioning Scoping Study, DPST-85-793, June 1986.

4. H. E. Hootman, "Characterization of Solid Transuranic Wastes Being Stored at SRP", DPST-78-326, June 14, 1978. 
Table 1 Alpha Waste Categories

\begin{tabular}{|lll}
\hline Category & Type & Volume, cu.ft. Activity, $\mathrm{Ci} \%$ Volume \% Activity \\
\hline
\end{tabular}

\begin{tabular}{|llrrrr|}
\hline 1. WIPP Qualified & Drums & 7563 & 1311 & & \\
(Alpha wastes have & Boxes & 55851 & 10660 & & \\
Halflife $>20$ years & Culvert & 53424 & 97618 & & \\
and are $>100 \mathrm{nCi} / \mathrm{g}$ ) & Sub-Total & 116838 & 109589 & 11.33 & 13.04 \\
\hline
\end{tabular}

\begin{tabular}{|llrlll|}
\hline 2. Less than 10nCi/g & Drums & 104536 & 76 & & \\
& Boxes & 39407 & 12 & & \\
& Culvert & 949 & 11 & & \\
& Sub-Total & 144892 & 99 & 14.05 & 0.01 \\
\hline
\end{tabular}

\begin{tabular}{|clrrrrr|}
\hline 3. Between 10 and & Drums & 20621 & 271 & & \\
$100 \mathrm{nCi} / \mathrm{g}$ & Boxes & 17983 & 145 & & \\
& Cuivert & 1398 & 85 & & \\
& Sub-Total & 40002 & 501 & 3.88 & 0.06 \\
\hline
\end{tabular}

\begin{tabular}{|llrrrr|}
\hline 4. Exceeds WIPP & Non-Culvert & 0 & 0 & & \\
Waste Acceptance & Culvert & 10005 & 234370 & & \\
Criteria & Sub-Total & 10005 & 234370 & 0.97 & 27.89 \\
\hline
\end{tabular}

\begin{tabular}{|llrrrr|}
\hline 5. Unaddressed & Non-Culvert & 0 & 0 & & \\
Concrete Pours & Culvert & 62192 & 231930 & & \\
Cm, Cf, high Pu-238. & Sub-Total & 62192 & 231930 & 6.03 & 27.60 \\
\hline
\end{tabular}

\begin{tabular}{|c|c|c|c|c|c|}
\hline $\begin{array}{l}\text { 6. Non-TRU } \\
\text { Induced Activity } \\
\text { Fission Products }\end{array}$ & $\begin{array}{l}\text { Non-Culvert } \\
\text { Culvert } \\
\text { Sub-Totai }\end{array}$ & $\begin{array}{l}23213 \\
11963 \\
35176\end{array}$ & $\begin{array}{l}0 \\
0 \\
0\end{array}$ & 3.41 & 0.00 \\
\hline Retrievable 7 & Total, FY1994 & 409105 & 576489 & 39.68 & 68.61 \\
\hline
\end{tabular}

\begin{tabular}{|llrrrrr|}
\hline 7. Projected D\&D and & Non-Culvert & 594424 & 33800 & & \\
Operations Generated & Culvert & 27610 & 230007 & & \\
Wastes,1994-2023 & Sub-Total & 622034 & 263807 & 60.32 & 31.39 \\
\hline Retrievable TRU & Total, FY2023 & 1031139 & 840296 & 100.00 & 100.00 \\
\hline
\end{tabular}

NOTE: The alpha waste categories are more fully defined in Table 3. 


\begin{tabular}{|lllll}
\hline Category & Type & Volume, cu.ft. Activity, Ci $\%$ Volume & $\%$ Activity \\
\hline
\end{tabular}

\begin{tabular}{|llrrrr|}
\hline 1. WIPP Qualified & Drums & 24294 & 4859 & & \\
Alpha wastes have & Boxes & 179404 & 39543 & & \\
halfife $>20$ years & Culvert & 72392 & 165240 & & \\
and $>100$ nCi/g & Sub-Total & 276090 & 209642 & 26.78 & 24.95 \\
\hline
\end{tabular}

\begin{tabular}{|c|c|c|c|c|}
\hline $\begin{array}{l}\text { 2. Less than } 10 \mathrm{nCi} / 9 \text { Drums } \\
\qquad \begin{array}{l}\text { Boxes } \\
\text { Culvert } \\
\text { Sub-Total }\end{array}\end{array}$ & $\begin{array}{r}335490 \\
126335 \\
1348 \\
463173\end{array}$ & $\begin{array}{r}282 \\
44 \\
11 \\
337\end{array}$ & 44.92 & 0.04 \\
\hline
\end{tabular}

\begin{tabular}{|clrrrr|}
\hline 3. Between 10 and & Drums & 66027 & 1005 & & \\
$100 \mathrm{nCi} / \mathrm{g}$ & Boxes & 57580 & 528 & & \\
& Culvert & 1832 & 145 & & 0.20 \\
& Sub-Total & 125439 & $16 \% 8$ & 12.17 & \\
\hline
\end{tabular}

\begin{tabular}{|llrrrr|}
\hline 4. Exceeds WIPP & Non-Culvert & 0 & 0 & & \\
Waste Acceptance & Culvert & 13558 & 396709 & & \\
Criteria & Sub-Total & 13558 & 396709 & 1.31 & 47.21 \\
\hline
\end{tabular}

\begin{tabular}{|llrrrr|}
\hline 5. Unaddressed & Non-Culvert & 0 & 0 & & \\
Concrete Pours & Culvert & 62192 & 231930 & & \\
Cm,Cf, high Pu-238 & Sub-Total & 62192 & 231930 & 6.03 & 27.60 \\
\hline
\end{tabular}

\begin{tabular}{|llllll|}
\hline 6. Non-TRU & Non-Culvert & 74475 & 0 & & \\
Induced Activity & Culvert & 16212 & 0 & & \\
Fission Products & Sub-Total & 90687 & 0 & 8.79 & 0.00 \\
\hline & TOTAL & 1031139 & 840296 & 100 & 100
\end{tabular}

NOTE: The Alpha Waste Catergories are more fully defined in Table 3.

The distribution of the relative volumes and activities in the predicted alpha wastes are assumed to be the same as the stored wastes except for Category 5. 


\section{Table 3 Definition of Alpha Waste Categories}

Tables 1 and 2 summarize the current and future TRU waste disposition categories derived from COBRA records of low (druinmed and boxed waste $<0.5$ Curies per drum) and high activity (culvert stored wastes $>0.5$ Curies per drum). It appears that these alpha wastes can be can be effectively allocated into seven waste disposition categuries as follows:

Category 1. Waste that is greater than $100 \mathrm{nCi} / \mathrm{g}$ and has a half-life less than 20 years that can go to WIPP with little or no processing if they can be fit into DOT approved containers. Qualified culvert waste and boxed waste may need to be removed from their secondary containers.

Category 2. Waste that is less than $10 \mathrm{nCi} / \mathrm{g}$ will stay at SRS. This waste might be considered mixed waste because TRU mixed waste was not segregated until about 1988. COBRA does not identify mixed wastes. Since 1988, less than 10,000 cu. $\mathrm{ft}$. of all TRU wastes have been entered in COBRA.

Category 3. Waste that is between 10 and $100 \mathrm{nCi} / \mathrm{g}$ and is proclaimed mixed waste will stay at SRS. This waste category exists because the lcwer limit definition of TRU was changed in 1984.

Category 4. Waste that exceeds WIPP Waste Acceptance Criteria (WAC). This waste exceeds the gas generation limit of $130 \mathrm{Ci}$ per drum or exceeds the $150 \mathrm{~g}$ per container criticality limit for $\mathrm{Pu}-239$. The drum limit for $\mathrm{Pu}$ 239 is 195 grams, however the container limit was used because of boxed wastes also being in culverts.

Category 5. Waste that WM considers an ER problem and is not addressed in the current WM strategic plan. The Curium and Californium are not considered transuranic because of their short half-lives. This waste includes offsite shipments from Mound and Los Alamos.

Category 6. Waste that is not transuranic and non alpha emitting. This waste is fission products (FP), induced activity (IA) and various forms of uranium and other reactor target matrix materials that ended up mixed in with the transuranic wastes.

Category 7. Projected TRU waste receipts during the period ending 2022 (assumes no prior shipments of TRU waste to a national transuranic waste repository). Projected waste volumes were taken from Table 5. Projected waste activities were derived from data of isotope weight per unit volume of waste from Table 8. 
Table 4 Historical Culvert TRU Waste Receipts

\begin{tabular}{|c|c|c|c|c|c|c|c|c|c|c|c|c|c|c|}
\hline Yer & & ep-msc & DeQ-NND & 773.1 & $772 \cdot F$ & $235 \cdot F$ & 221.7 & $221 \cdot F B L$ & $221-F J 8$ & $221 \cdot H$ & $221 \cdot+92$ & $105 \cdot K$ & Mecelanoous & TOTAL \\
\hline \multicolumn{15}{|c|}{ 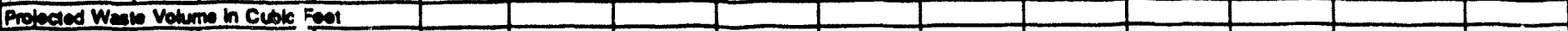 } \\
\hline 1064 & & & & & & & & & & & & & & 0 \\
\hline 1005 & & & & 10 & & & & & & & & & & 10 \\
\hline 1068 & & & & 63 & 255 & 130 & 806 & & & 388 & 70 & & 50 & 1541 \\
\hline 1087 & & & & 203 & 172 & 84 & 100 & & & 23 & & & & 721 \\
\hline 1088 & & & & 437 & 142 & & 638 & & ee & 263 & 20 & & & 1707 \\
\hline 1000 & & & & 4442 & 121 & 320 & 837 & & & 208 & 24 & & & 6018 \\
\hline 1070 & & & & 2080 & 87 & & & & & & & & & 3067 \\
\hline 1071 & & 473 & 0808 & 1707 & 318 & 1100 & 647 & & 780 & 256 & 300 & & & 14403 \\
\hline 1072 & & 108 & 110 & 2498 & 20 & 374 & & 86 & 1400 & & 471 & 502 & & 8334 \\
\hline 1078 & & & & 2534 & 236 & 162 & & & 850 & & 360 & 334 & 210 & $\$ 404$ \\
\hline 1074 & & & & 1063 & 164 & 0 & 7 & & 512 & & 672 & 120 & 80 & 3460 \\
\hline 1078 & & & & 1002 & 355 & 120 & & & 392 & & 226 & 713 & 44 & 3760 \\
\hline 1078 & & & & 1268 & 491 & 46 & 28 & 42 & 407 & & 446 & 116 & 3 & 3000 \\
\hline 1077 & & & & 34 & 302 & 23 & & 276 & 314 & 7 & 615 & 117 & & 2108 \\
\hline 1070 & & & & 288 & 408 & 205 & & Dos & & 4 & 254 & & 06 & 2306 \\
\hline 1070 & & & & 202 & 687 & os1 & & 010 & & & 423 & 308 & & 3160 \\
\hline 1000 & & & & 240 & (54) & 1018 & & 600 & 48 & & 896 & 136 & & 4184 \\
\hline 1001 & & & & 326 & 740 & 1110 & & 1201 & & & 770 & 270 & & 4028 \\
\hline 122 & & & & 157 & 702 & 00 & & 1102 & & & 1010 & 708 & 10 & 4720 \\
\hline 100 & & 001 & & 47 & 867 & 796 & & 220 & & & 27 & 270 & 7 & 4702 \\
\hline 1004 & & & & 2285 & 409 & 1080 & & 1836 & & & 1177 & 605 & 28 & 8703 \\
\hline 100 & & & & 14 & 368 & 38 & & 2104 & & & 800 & & 21 & 3170 \\
\hline 1000 & & & & 7 & 328 & & & 2248 & & & 218 & 240 & & 4646 \\
\hline 1007 & & & & & 68 & & & 1000 & & & en & & & F15 \\
\hline 100 & & & & & 104 & & & 1770 & & & 254 & & & 2516 \\
\hline 100 & & 120 & & 1 & 38 & 108 & & 1204 & & & 742 & & & 8214 \\
\hline 1000 & & & & 20 & 08 & 300 & & 700 & & & 208 & 01 & 7 & 2003 \\
\hline 1001 & & & & & 14 & 213 & & 248 & & & B11 & & & 1081 \\
\hline 1092 & & & & & 14 & 14 & & 38 & & & 448 & & & B11 \\
\hline & & & & & & & & & & & & & & \\
\hline Toid W-in & ond & 2008 & 2218 & 29000 & 0220 & 0142 & 2010 & 18780 & 4008 & 1310 & 13800 & 4503 & 842 & 100663 \\
\hline
\end{tabular}

Table 5 Historical Non-Culvert TRU Waste Receipts

\begin{tabular}{|c|c|c|c|c|c|c|c|c|c|c|c|}
\hline Yer & & $77^{2 \cdot n}$ & $770 \cdot F$ & $238-F$ & $221 . F$ & E21-FBL & 21-FJ日 & $221+4$ & $21++B 2$ & Meverencens & TOTA \\
\hline & & & & & & & & & & & \\
\hline \multicolumn{12}{|c|}{ 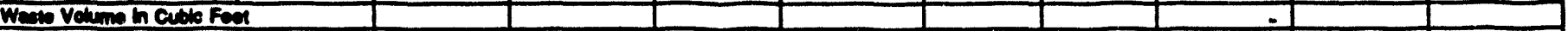 } \\
\hline 1074 & & 814 & 102 & 104 & & & 208 & & 200 & & 1018 \\
\hline 1078 & & 674 & 370 & 270 & & 7 & 1477 & 112 & $\theta$ & 80 & 2070 \\
\hline 1170 & & 700 & 002 & 06 & & 81 & 078 & 64 & 60 & 28 & 2629 \\
\hline 1077 & & e71 & 1049 & (i) & 7 & 707 & 240 & & 210 & 77 & 4020 \\
\hline 1970 & & 1267 & 60 & 0 & & 2402 & & & 102 & & 4760 \\
\hline 1070 & & 1200 & 2100 & 960 & & 1049 & & & 300 & 112 & 6278 \\
\hline 1000 & & 1005 & 1800 & 1110 & & 3939 & 7 & & 1009 & 203 & 2100 \\
\hline 1081 & & 1860 & 2101 & 1741 & & 3612 & & & 1880 & & 10003 \\
\hline 1082 & & 1108 & 1368 & 1689 & & 3601 & & & 1551 & & 0228 \\
\hline 1993 & & 1843 & 1860 & 490 & & 3670 & 108 & & 003 & & 8408 \\
\hline 1004 & & 1914 & 1602 & 180 & & 5806 & & & 1903 & & 10864 \\
\hline 1885 & & 1484 & 1236 & & & 8410 & & & 4529 & 7) & 15672 \\
\hline 1086 & & 610 & 808 & 4 & if & 21403 & & & 6700 & & 20304 \\
\hline 1087 & & 543 & 572 & & & 7700 & & & 10672 & & 10487 \\
\hline 1080 & & 367 & 410 & & & 14063 & & & 3864 & 00 & 18704 \\
\hline 1009 & & 360 & 287 & & & 6845 & & & 1400 & & 7802 \\
\hline 1000 & & 320 & 217 & 77 & & 21040 & & & 10801 & 77 & 33340 \\
\hline 1201 & & 201 & 200 & & & 10320 & & & 36351 & 52 & 85214 \\
\hline 1002 & & 103 & 63 & & & 476 & & & of & & .42 \\
\hline & & & & & & & & & & & \\
\hline \multicolumn{2}{|c|}{ Toral Worle Rocalved } & 18127 & 16802 & 6220 & 7 & 123398 & 4215 & 168 & 81743 & 710 & 251203 \\
\hline
\end{tabular}




\section{Table 6 HB-Line D\&D Waste Generation Data}

\begin{tabular}{|c|c|c|c|c|c|c|c|c|}
\hline Yer, CY & Varieby & Containe & Cora & Culwert & nom-Culvent & Low Aphe & Low Lovel & Number of \\
\hline & & & Gram & Cubic Fen & Cuble Fent & Arh Woste & Beteamma C & Containers \\
\hline & & & & & & Cubie Fel & Cubic Feot & \\
\hline & & & & & & & & \\
\hline \multirow[t]{13}{*}{1084} & $\boldsymbol{P}$ & $\mathrm{B}-25$ & 0 & & & 864 & & 10 \\
\hline & $\mathbf{F}$ & $8-25$ & 0. & & & & 672 & 7 \\
\hline & $\boldsymbol{P}$ & 83 & 요 & & & & 201 & 25 \\
\hline & Np-237 & Drum & 0 & 7 & & & & 1 \\
\hline & Pu-200 & $E 3$ & 1.7 & 700 & & & & 80 \\
\hline & Pu-238 & Drum & 700 & 460 & & & & 67 \\
\hline & Pu-230 & B-12 & 0 & & & 402 & & 0 \\
\hline & Pu-230 & $\mathrm{B}-25$ & 0.021 & & & 6048 & & 97 \\
\hline & $P u-238$ & $\mathrm{~EB}$ & 0 & & & 1022 & & 120 \\
\hline & Pu-238 & Whec & o. & & & 3234 & & \\
\hline & Pu-230 & B-25 & 0.003 & & & & 1728 & 10 \\
\hline & $\mathrm{Pu}-236$ & $E$ & 0 & & & & 162 & 23 \\
\hline & Pu-200 & Drum & 0 & & 1306 & & & 108 \\
\hline & & & & & & & & \\
\hline & & & & & & & & \\
\hline \multirow[t]{5}{*}{1085} & $\mathrm{Pu}-238$ & Drum & 1413 & 553 & & & & 70 \\
\hline & Pu-225 & Mine & 2.54 & 16 & & & & 2 \\
\hline & Pu-230 & B-25 & 0.01 & & & & 14880 & 165 \\
\hline & Pu-230 & $E$ & 0 & & & & 162 & 20 \\
\hline & Pu-230 & Drum & 의 & & 4520 & & & 647 \\
\hline & & & & & & & & \\
\hline & & & & & & & & \\
\hline \multirow[t]{5}{*}{1986} & Np-237 & Drum & 0 & & 7 & & & 1 \\
\hline & Pu-238 & $\mathrm{B}-25$ & of & & & & 0000 & 100 \\
\hline & Pu-208 & B-25 & of & & 20 & & & 1 \\
\hline & Pu-238 & 8 & 111.5 & & 1300 & & & 1 \\
\hline & Pu-236 & Drum & 0 & & 1050 & & & 150 \\
\hline & & & & & & & & \\
\hline & & & & & & & & \\
\hline \multirow[t]{5}{*}{1087} & $N_{p} \cdot 237$ & Drum & 0 & 16 & & & & 2 \\
\hline & Np-237 & Miec & 0 & & & & 40 & \\
\hline & Pu-230 & Drum & 671 & 873 & & & & 125 \\
\hline & Pu-238 & 83 & of & & & & 360 & 45 \\
\hline & Pu-230 & 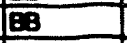 & 264.1 & & 8080 & & & 4 \\
\hline & & & & & & & & \\
\hline & & & & & & & & \\
\hline \multirow[t]{2}{*}{1088} & Np-237 & Drum & 0 & & 7 & & & 1 \\
\hline & Pu-290 & Drum & 275 & 334 & & & & 40 \\
\hline & & & & & & & & \\
\hline & & & & & & & & \\
\hline \multirow[t]{7}{*}{1089} & Np-237 & Drum & of & 39 & & & & 5 \\
\hline & No-237 & Drum & Q & & 28 & & & 4 \\
\hline & $P_{u-238}$ & Drum & 103 & 700 & & & & 25 \\
\hline & Pu-230 & B-25 & 0 & & & & 8820 & 08 \\
\hline & Pu-230 & Drum & & & 712 & & & 97 \\
\hline & $P_{u-238}$ & $E$ & & & 1500 & & & 1 \\
\hline & Pu-238 & Fller Box & & & & & 128 & 16 \\
\hline & & & & & & & & \\
\hline \multirow[t]{4}{*}{1090} & Np-237 & Dnum & 1004 & 63 & & & & 2 \\
\hline & Pu-238 & $8-25$ & 0 & & & & 18090 & 201 \\
\hline & Pu-238 & $\mathrm{EB}$ & 83 & & 10584 & & & 7 \\
\hline & Pu-230 & Fither Box & 0 & & & & 80 & 10 \\
\hline & & & & & & & & \\
\hline & & & & & & & & \\
\hline \multirow[t]{3}{*}{1091} & Pu-230 & $\mathrm{B}-25$ & 0 & & & & 8280 & 92 \\
\hline & Pu-238 & 88 & 70 & & 36280 & & & 24 \\
\hline & $P_{u-238}$ & Fillor Box & 0 & & & & 64 & 의 \\
\hline & & & & & & & & \\
\hline \multirow[t]{3}{*}{1992} & Pu-238 & B-25 & of & & & & 360 & 4 \\
\hline & Pu-238 & B.12 & 0 & & & & 450 & \\
\hline & Pu-238 & B.25 & 0 & & & & 12600 & 140 \\
\hline & & & & & & & & \\
\hline 1993 & $P_{U-238}$ & B.25 & & & & & 16920 & 188 \\
\hline & & & & & & & & \\
\hline 1894 & Pu-238 & $E 8$ & & & 40824 & & & 27 \\
\hline & & & & & & & & \\
\hline Total & & & 5607 & 3778 & 104585 & 11570 & 92997 & \\
\hline
\end{tabular}


Table 7 FB-Line D\&D Waste Generation Data

\begin{tabular}{|c|c|c|c|c|c|c|c|c|}
\hline Year & Varioty & Container & $\cos x$ & Culvent & non-Culvart & Concrote & Low Level & Low Lovel \\
\hline & & & Grams & Cuble Feet & Cublic Foot & Pour & Alpha Wastc & Beta-Gamma \\
\hline & & & & & & Cuble Feat & Cubic Feot & Cublic Foot \\
\hline & & & & & & & & \\
\hline 1072 & Pu-239 & Drum & 21.4 & 6 & & & & \\
\hline & Pu-239 & Misc & 44 & 50 & & & & \\
\hline & Pu-239 & B-12 & 3.2 & & & 48 & & \\
\hline & Pu-230 & B-25 & 24 & & & 742 & & \\
\hline & Pu-239 & $E$ & 64 & & & 2963 & & \\
\hline & Pu-239 & Drum & 12.8 & & & 27 & & \\
\hline & Pu-239 & Mioce & 48 & & & 703 & & \\
\hline & Pu-239 & B-12 & 50.6 & 44 & & & & \\
\hline & PU-239 & EB & 6.4 & 540 & & & & \\
\hline & Pu-239 & Drum & 288 & 178 & & & & \\
\hline & Py-239 & Mies & 680 & 638 & & & & \\
\hline & Pu-239 & B-12 & 0.16 & & & & 1243 & \\
\hline & Pu-239 & B-25 & 0.795 & & & & 1713 & \\
\hline & Pu-230 & EB & 12.12 & & & & 11034 & \\
\hline & Pu-230 & Drum & 3.84 & & & & 48 & \\
\hline & Pu-239 & $m x$ & 0.74 & & & & 8639 & \\
\hline & $P_{c-230}$ & Drum & 4.72 & & & & & 1 \\
\hline & & & & & & & & \\
\hline 1073 & $\Phi$ & $\min$ & 0 & & & & 27 & \\
\hline & F & $E$ & 0 & & & & & 302 \\
\hline & $\mathbf{P}$ & Minc & 0 & & & & & 80 \\
\hline & Pu-239 & $\mathrm{B}-12$ & 0 & & & 48 & & \\
\hline & Pu-239 & B.25 & 9.6 & & & 282 & & \\
\hline & Pu-239 & $E$ & 41.6 & & & 2644 & & \\
\hline & Pu-2398 & Mix & 12 & & & 164 & & \\
\hline & Pu-239 & EB & 6.24 & 160 & & & & \\
\hline & Pu-239 & Drum & 1148 & 336 & & & & \\
\hline & Pu-239 & max & 177 & 83 & & & & \\
\hline & Pu-230 & B-12 & 21.4 & & & & 862 & \\
\hline & Pu-230 & $B-25$ & 19.08 & & & & 1064 & \\
\hline & Pu-230 & $E$ & 18.2 & & & & 10784 & \\
\hline & Pu-239 & Drum & 0 & & & & 14 & \\
\hline & Pu-239 & Nix & 232.5 & & & & 11018 & \\
\hline & Pu-239 & Mine & 3.52 & & & & & 28 \\
\hline & & & & & & & & \\
\hline 1974 & Pu-239 & Drum & 1359.8 & 361 & & & & \\
\hline & Pu-230 & $\sqrt{100}$ & 414.12 & 151 & & & & \\
\hline & Pu-239 & B-12 & 0 & & & & 752 & \\
\hline & Pu-239 & $\mathrm{B}-25$ & 0 & & & & 387 & \\
\hline & Pu-239 & $E B$ & 0 & & & & 734 & \\
\hline & Pu-239 & Drum & 0 & & & & 13 & \\
\hline & Pu-239 & Misc & 26.24 & & & & 8646 & \\
\hline & Pu-239 & B-12 & 0 & & & & & 90 \\
\hline & Pu-239 & Mise & 0 & & & & & 244 \\
\hline & Pu-239 & Drum & 의 & & 805 & & & \\
\hline & Pu-238 & Nisco & 0 & & & & 26 & \\
\hline & & & & & & & & \\
\hline & & & & & & & & \\
\hline & & & & & & & & \\
\hline
\end{tabular}


Table 7 FB-Line D\&D Waste Generation Data

\begin{tabular}{|c|c|c|c|c|c|c|c|c|}
\hline Year & Tarioty & Contain & ग्कsa & Culvert & non-Culven & Concrote & Low Lovel & Low Levol \\
\hline & & & Grams & Cuble Foet & Cubic Feot I & Pour & Alpha Wastde & Bota-Gamma \\
\hline & & & & & & Cubic Foet & Cubic Feot & Cubic Foet \\
\hline & & & & & & & & \\
\hline 1075 & $\bar{P}$ & Mise & 0 & & & & & 64 \\
\hline & Dు & Drum & 0. & 6] & & & & \\
\hline & Pu.239 & Drum & 1530.18 & 384 & & & & \\
\hline & Pu-239 & $\overline{B-12}$ & 0 & & & & 858 & \\
\hline & Pu-239 & B-25 & 0 & & & & 194 & \\
\hline & Pu-239 & EB & o & & & & 1045 & \\
\hline & Pu-239 & Drum & 0 & & & & 20 & \\
\hline & PU-239 & Misec & 0.1 & & & & 5568 & \\
\hline & Pu-239 & B.12 & 0 & & & & & 92 \\
\hline & Pu-239 & Drum & o & & & & & 9 \\
\hline & Pu-230 & Misc & 0 & & & & & 350 \\
\hline & Pu-239 & Drum & 19.06 & & 1477 & & & \\
\hline & Nat U & Drum & 0 & 2 & & & & \\
\hline & & & & & & & & \\
\hline 1978 & Pu-230 & Drum & 1830.34 & 497 & & & & \\
\hline & Pu-239 & $B-12$ & 0 & & & & 680 & \\
\hline & Pu-239 & B.25 & 01 & & & & 852 & \\
\hline & Pu-230 & 58 & of & & & & 1483 & \\
\hline & Pu-239 & Drumi & 0 & & & & 49 & \\
\hline & Pu-239 & Min: & 0 & & & & 5584 & \\
\hline & Pu-239 & B-12 & 0 & & & & & 48 \\
\hline & Pu-230 & Mace & o. & & & & & 115 \\
\hline & Pu-239 & Drum & 5 & & 875 & & & \\
\hline & & & & & & & & \\
\hline 1977 & $\mathbf{P}$ & $\min$ & 의 & & & & 126 & \\
\hline & б & Mix & 0 & & & & 10 & \\
\hline & Pu-239 & Drum & 1255.58 & 301 & & & & \\
\hline & Pu-239 & Mise & 1.86 & 13 & & & & \\
\hline & Pu-239 & B-12 & of & & & & 790 & \\
\hline & Pu-239 & B-25 & 0 & & & & 384 & \\
\hline & Pu-239 & EB & 0 & & & & 844 & \\
\hline & Pu-239 & Drum & 0 & & & & 30 & \\
\hline & Pu-239 & Wix & 0. & & & & 4288 & \\
\hline & Pu-230 & Drum & 의 & & & & & 8 \\
\hline & Pu-239 & $\operatorname{mix}$ & 0 & & & & & 60 \\
\hline 1977 & Pu-239 & Drum & 의 & & 939 & & & \\
\hline 1978 & P1-230 & का & 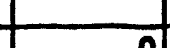 & & & & 102 & \\
\hline & & & & & & & & \\
\hline 1980 & Pu-239 & Drum & 36.3 & 14 & & & & \\
\hline & PU-239 & Mix & 10.49 & 31 & & & & \\
\hline & Pu-239 & EB & 0 & & & & 108 & \\
\hline & Pu-239 & Misc & 0 & & & & 86 & \\
\hline & Pu-239 & Drum & 3.5 & & 7 & & & \\
\hline & & & & & & & & \\
\hline 1983 & Pu-239 & EB & 0 & & & & 444 & \\
\hline & Pu-239 & Drum & 의 & & 105 & & & \\
\hline Total & & & 9464.49 & 3775 & 4208 & 7619 & 81549 & 1491 \\
\hline
\end{tabular}




\section{Table 8 Definition of D\&D Critical Planning Parameters}

A. Old HB-Line

D\&D Floor Area sq. ft.

Cleanup Time, Years

Cost, \$Millions

Man-years

5,000

8

12.5

2.50

TRU Waste Isotope Volume, cu. ft. Grams Curies (As generated)
a. Culvert
Pu-238
3778
3175
54,610
b. Non-Culvert
Pu-238
104,585
529
9,099
c. Total
108,360

B. Old FB-Line

D\&D Floor Area sq. $\mathrm{ft}$.

Cleanup Time, Years

7,500

6

TRU Waste

Isotope

Volume, cu. ft. Grams

Curies (As generated)

a. Culvert

Pu-239

3775

.8869

552

b. Non-Culvert

Pu-239

93,376

571

36

c. Total

97,151

C. Waste Generation and Characterization Factors

1. Culvert fraction of Waste Volume 4 percent

2. D\&D TRU Waste Generation Factors:

a. Pu-238 is 21 cubic feet per sq.foot contaminated floor area.

b. Pu-239 is 13 cubic feet per sq.foot contaminated floor area.

3. Projected waste activities were derived from data of isotope weight per unit volume of waste from Tables 4 and 5 as follows:

$\begin{array}{ccr}\frac{\text { Isotope }}{\mathrm{Pu}-238} & \frac{\text { Culvert }}{0.84 \mathrm{~g} / \mathrm{ft} 3} & \frac{\text { Non-Culvert }}{0.005 \mathrm{~g} / \mathrm{ft} 3} \\ \mathrm{Pu}-239 & 2.35 \mathrm{~g} / \mathrm{ft} 3 & 0.006 \mathrm{~g} / \mathrm{ft} 3\end{array}$




\section{Table 9 Projected Alpha Wastes}

\begin{tabular}{|c|c|c|c|c|c|c|c|}
\hline Year & $773 . A$ & $772 \cdot F$ & $235 \cdot F$ & $221-F B L$ & $221-H B L$ & Complex 21 Vault & TOTAL \\
\hline \multicolumn{8}{|c|}{ Waste Volume in Cubic Feet } \\
\hline & & & & & & & \\
\hline 1993 & 110 & 220 & & 687 & 800 & & 1817 \\
\hline 1994 & 110 & 550 & & 2000 & 41794 & & 44454 \\
\hline 1995 & 10000 & 550 & & 2000 & 25770 & & 38320 \\
\hline 1996 & 10000 & 550 & 10000 & 2000 & 25770 & & 48320 \\
\hline 1997 & 10000 & 550 & 20000 & 2000 & 25200 & & 57750 \\
\hline 1998 & 10000 & 550 & 20000 & 2000 & $190 \mathrm{C}$ & & 34450 \\
\hline 1999 & 110 & 550 & 20000 & 2000 & 1900 & & 24560 \\
\hline 2000 & 110 & 550 & 20000 & 2000 & 1900 & & 24560 \\
\hline 2001 & & 550 & 20000 & 2000 & 1900 & & 24450 \\
\hline 2002 & & 550 & 20000 & 2000 & 1100 & & 23650 \\
\hline 2003 & & 550 & 10000 & 2000 & 10000 & & 22550 \\
\hline 2004 & & 550 & & 2000 & 20000 & & 22550 \\
\hline 2005 & & 550 & & 2000 & 20000 & 1000 & 23550 \\
\hline 2006 & & 330 & & 1413 & 20000 & 2000 & 23743 \\
\hline 2007 & & 330 & & 900 & 20000 & 2000 & 23230 \\
\hline 2008 & & 330 & & - & 20000 & 2000 & 22330 \\
\hline 2009 & & 330 & & & 20000 & 2000 & 22330 \\
\hline 2010 & & 330 & & 7200 & 10000 & 2000 & 19530 \\
\hline 2011 & & 330 & & 14400 & & 2000 & 16730 \\
\hline 2012 & & 330 & & 14400 & & 2000 & 16730 \\
\hline 2013 & & 220 & & 14400 & & 2000 & 16620 \\
\hline 2014 & & 220 & & 14400 & & 2000 & 16620 \\
\hline 2015 & & 220 & & 14400 & & 2000 & 16620 \\
\hline 2016 & & 110 & & 14400 & & 2000 & 16510 \\
\hline 2017 & & 110 & & 7200 & & 2000 & 9310 \\
\hline 2018 & & 110 & & & & 2000 & 2110 \\
\hline 2019 & & 110 & & & & 2000 & 2110 \\
\hline 2020 & & 110 & & & & 2000 & 2110 \\
\hline 2021 & & 110 & & & & 2000 & 2110 \\
\hline 2022 & & 110 & & & & 2000 & 2110 \\
\hline 2023 & & & & & & 200 & 200 \\
\hline & & & & & & & \\
\hline Total Waste & 40440 & 10560 & 140000 & 127800 & 268034 & 35200 & 622034 \\
\hline
\end{tabular}


Table 10 Projected Culvert TRU Waste Receipts

\begin{tabular}{|c|c|c|c|c|c|c|c|c|}
\hline Yon & & $773 \cdot A$ & $772 \cdot F$ & 235.F & $221 \cdot \mathrm{FBL}$ & $221-1 \mathrm{BL}$ & Complex 21 Vach & TOTN \\
\hline \multirow{2}{*}{\multicolumn{9}{|c|}{ Proinacd Weis Volume in Cloic Feet }} \\
\hline & & & & & & & & \\
\hline 1009 & & & 20 & & 200 & 800 & & 1020 \\
\hline 1004 & & 10 & 50 & & 200 & 970 & & 1250 \\
\hline 1005 & & 400 & 50 & & 200 & 070 & & 1620 \\
\hline 1008 & & 400 & 80 & 400 & 200 & 070 & & 2020 \\
\hline 1007 & & 400 & 50 & 800 & 200 & 400 & & 1850 \\
\hline 1008 & & 400 & 80 & 800 & 200 & 100 & & 1550 \\
\hline 190 & & 10 & 50 & 100 & 200 & 100 & & 1180 \\
\hline 2000 & & 10 & 50 & 00 & 200 & 100 & & 1160 \\
\hline 2001 & & & 80 & 800 & 200 & 100 & & 1150 \\
\hline 2002 & & & 80 & 100 & 200 & 100 & & 1150 \\
\hline 2003 & & & 60 & 400 & 200 & 400 & & 1050 \\
\hline 2004 & & & 50 & & 200 & 800 & & 1050 \\
\hline 2005 & & & 80 & & 200 & 800 & 100 & 1150 \\
\hline 2008 & & & 30 & & 100 & 200 & 200 & 1130 \\
\hline 2007 & & & 30 & & & 800 & 200 & 1030 \\
\hline 2000 & & & 20 & & & 800 & 200 & 1030 \\
\hline 2000 & & & 30 & & & 000 & 200 & 1030 \\
\hline 2010 & & & 30 & & 200 & 400 & 200 & 890 \\
\hline 2011 & & & 30 & & 400 & & 200 & 030 \\
\hline 2012 & & & 30 & & 400 & & 200 & 630 \\
\hline 2018 & & & 20 & & 400 & & 200 & 020 \\
\hline 2014 & & & 20 & & 400 & & 200 & 020 \\
\hline 2018 & & & 20 & & 400 & & 200 & 020 \\
\hline 2016 & & & 10 & & 400 & & 200 & 810 \\
\hline 2017 & & & 10 & & 200 & & 200 & 410 \\
\hline 2010 & & & 10 & & & & 200 & 210 \\
\hline 2010 & & & 10 & & & & 200 & 210 \\
\hline 8020 & & & 10 & & & & 200 & 210 \\
\hline 2021 & & & 10 & & & & 200 & 210 \\
\hline 802 & & & 10 & & & & 200 & 210 \\
\hline 2020 & & & 10 & & & & 200 & 210 \\
\hline & & & & & & & & \\
\hline Ted fretinend & When & 1090 & 270 & 800 & 5800 & 10210 & 3700 & 27810 \\
\hline
\end{tabular}

\section{Table 11 Projected Non-Culvert TRU Waste Receipts > $100 \mathrm{nCi} / \mathrm{g}$}

\begin{tabular}{|c|c|c|c|c|c|c|c|c|}
\hline Yor & & $\pi x-A$ & $7 \pi \cdot F$ & ESF & E1Fa & $221+12$ & Coning 21 Vent & TOTN \\
\hline \multicolumn{9}{|c|}{ 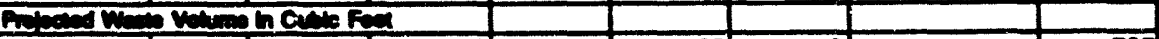 } \\
\hline 109 & & 24 & 40 & & 407 & (2) & & 767 \\
\hline 104 & & 24 & 120 & & 420 & 017 & & 10109 \\
\hline $10 \mathrm{~s}$ & & 2205 & 110 & & 420 & 8002 & & 2735 \\
\hline 1906 & & 220 & 110 & 2205 & 48 & 8002 & & 11020 \\
\hline IDer & & 220 & 110 & 450 & 420 & 5002 & & 13905 \\
\hline 100 & & 2208 & 110 & 4570 & 420 & 48 & & 7032 \\
\hline 100 & & 24 & 110 & 4670 & 420 & 420 & & 6571 \\
\hline 2000 & & 24 & 110 & 4570 & 420 & Q21 & & 8571 \\
\hline 2001 & & & 110 & 4870 & 429 & 420 & & sed \\
\hline 2002 & & & 110 & 4570 & 480 & 20 & & 6356 \\
\hline 2009 & & & 110 & 228 & 420 & 2208 & & 8119 \\
\hline 2004 & & & 110 & & 480 & 4670 & & 5110 \\
\hline 2005 & & & 110 & & 480 & 8670 & 218 & 5393 \\
\hline 2000 & & & 72 & & S19 & 4570 & 420 & 8304 \\
\hline 2007 & & & 72 & & 215 & 4670 & 420 & 8200 \\
\hline 2008 & & & 72 & & & 4570 & 420 & 6071 \\
\hline 2000 & & & 72 & & & 4570 & 420 & 8071 \\
\hline 2010 & & & 72 & & 1868 & 2285 & 420 & 4452 \\
\hline 2011 & & & 72 & & 3332 & & 420 & 2039 \\
\hline 2012 & & & 72 & & 3932 & & 420 & 3033 \\
\hline 2013 & & & 40 & & 3332 & & 420 & 3800 \\
\hline 2014 & & & 40 & & 3532 & & 428 & 3800 \\
\hline 2015 & & & 48 & & 3332 & & 420 & 3000 \\
\hline 2016 & & & 24 & & 3332 & & 420 & 3785 \\
\hline 2017 & & & 24 & & 1686 & & 420 & 2110 \\
\hline 2010 & & & 24 & & & & 420 & 453 \\
\hline 2010 & & & 24 & & & & 420 & 453 \\
\hline 2020 & & & 24 & & & & 420 & 453 \\
\hline 2021 & & & 24 & & & & 420 & 453 \\
\hline 2022 & & & 24 & & & & 420 & 453 \\
\hline Sub-Tol Prol & and We & 0236 & 2292 & 31000 & 20487 & 61267 & 7500 & 142008 \\
\hline
\end{tabular}


Table 12 Projected Non-Culvert TRU Waste Receipts 10 to $100 \mathrm{nCi} / \mathrm{g}$

\begin{tabular}{|c|c|c|c|c|c|c|c|c|}
\hline i Yoer & & $773-A$ & $772 . F$ & $295-F$ & $221 . F \mathrm{FL}$ & $221+182$ & Comenox 21 Verte & TOTN \\
\hline \multicolumn{9}{|c|}{ 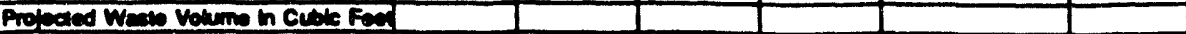 } \\
\hline 1099 & & 22 & 44 & & 108 & $\overline{0}$ & & 174 \\
\hline 1004 & & 22 & 111 & & 400 & 9003 & & 0506 \\
\hline 1003 & & 2131 & 111 & & 400 & 5806 & & 8148 \\
\hline 1000 & & 2131 & i11 & 2139 & 100 & 8500 & & 10270 \\
\hline 1007 & & 2131 & 111 & 4202 & 400 & 6806 & & 12410 \\
\hline 1000 & & 2131 & 111 & 4202 & 400 & 800 & & 7304 \\
\hline 1000 & & 22 & 111 & 4202 & 100 & 400 & & 8105 \\
\hline 2000 & & 22 & 111 & 4202 & 400 & 400 & & 8103 \\
\hline 2001 & & & 111 & 4212 & 100 & 100 & & 8173 \\
\hline 2002 & & & 111 & 4262 & $\$ 00$ & 222 & & 4995 \\
\hline 2003 & & & 111 & 2131 & 400 & 2191 & & 4779 \\
\hline 2004 & & & 111 & & 400 & $\$ 262$ & & 4779 \\
\hline 2006 & & & 111 & & 400 & 4262 & 200 & 4979 \\
\hline 2006 & & & 67 & & 292 & 4262 & 400 & 8021 \\
\hline 2007 & & & 87 & & 200 & 4262 & 400 & 4020 \\
\hline 2000 & & & 67 & & & 4262 & 400 & 4720 \\
\hline 2000 & & & 67 & & & 4262 & 800 & 4720 \\
\hline 2010 & & & e7) & & 1550 & 2131 & 900 & 4162 \\
\hline 2011 & & & en & & 3100 & & 400 & 3576 \\
\hline 2018 & & & 67 & & 3100 & & 900 & 2676 \\
\hline 2010 & & & 44 & & 2100 & & 400 & 3562 \\
\hline 2014 & & & (4) & & 3100 & & 400 & 2562 \\
\hline 2010 & & & 4 & & ग100 & & 100 & 2852 \\
\hline 8010 & & & I9 & & 2100 & & 400 & 2650 \\
\hline 2017 & & & 29 & & 1664 & & 400 & 1076 \\
\hline 8010 & & & 22 & & & & 400 & 428 \\
\hline 8010 & & & 22 & & & & 400 & 422 \\
\hline 2020 & & & 28 & & & & 100 & 422 \\
\hline 2021 & & & 29 & & & & $\$ 00$ & 422 \\
\hline 2022 & & & 82 & & & & 400 & 422 \\
\hline & & & & & & & & \\
\hline 年 & 4 & es121 & 2131 & 20294 & 27180 & 67237 & 7000 & 131070 \\
\hline
\end{tabular}

Table 13 Projected Non-Culvert TRU Waste Receipts < $10 \mathrm{nCi} / \mathrm{g}$

\begin{tabular}{|c|c|c|c|c|c|c|c|c|}
\hline Vere & & $\overline{7 r 3 \cdot A}$ & Tre-F & Ees-f & ERI.FEL & $221+21$ & Conging 21 Vees & TOTAL \\
\hline & & & & & & & & \\
\hline \multicolumn{9}{|c|}{ 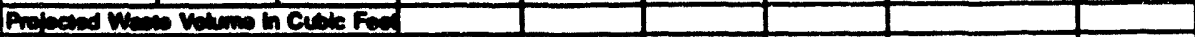 } \\
\hline Ine & & 40 & 102 & & 250 & 0 & & 400 \\
\hline 100 & & 40 & 804 & & 267 & 22090 & & 23910 \\
\hline 100 & & 8170 & 304 & & 067 & 13300 & & 18708 \\
\hline ing & & 517 & 204 & B104 & बहत्र & 13906 & & 2470 \\
\hline 1087 & & 5170 & 264 & 10200 & 867 & 12500 & & 20163 \\
\hline 1000 & & 8170 & 204 & 10200 & 267 & 00 & & 17743 \\
\hline 1000 & & 40 & 264 & 10200 & Q67 & Oed & & 12013 \\
\hline 2000 & & 40 & 204 & 1000 & 98 & 0 & & 12618 \\
\hline 2001 & & & 30 & 1090 & 887 & ese & & 12568 \\
\hline 2002 & & & 204 & 10200 & 067 & 638 & & 12134 \\
\hline 2009 & & & 24 & 510 & 067 & 8170 & & 11004 \\
\hline 2004 & & & 204 & & 00 & 10269 & & 11506 \\
\hline 2005 & & & 84 & & ece & 10309 & 400 & 12076 \\
\hline 2000 & & & 187 & & 704 & 10589 & Des & 12100 \\
\hline 2007 & & & 167 & & 481 & 10503 & 208 & 11067 \\
\hline 2000 & & & 167 & & & 10563 & 06 & 11480 \\
\hline 2000 & & & 167 & & & 10569 & 268 & 11486 \\
\hline 2010 & & & 157 & & 3774 & 6170 & 08 & 10070 \\
\hline 2011 & & & 167 & & 7854 & & 208 & 0677 \\
\hline 2012 & & & 157 & & 7854 & & 086 & 0677 \\
\hline 2013 & & & 108 & & 7854 & & 066 & 0622 \\
\hline 2014 & & & 102 & & 7654 & & 068 & 0822 \\
\hline 2015 & & & 102 & & 7554 & & 286 & 0622 \\
\hline 2010 & & & 40 & & 7554 & & 89 & 0580 \\
\hline 2017 & & & 40 & & 3774 & & Des & 4780 \\
\hline 2010 & & & 40 & & & & 268 & 1014 \\
\hline 2010 & & & 40 & & & & 060 & 1014 \\
\hline 2020 & & & 40 & & & & 088 & 1014 \\
\hline 20211 & & & 40 & & & & 260 & 1014 \\
\hline 2022 & & & 48 & & & & 088 & 1014 \\
\hline of Prolen & 1 & 20004 & so11 & 72570 & 65021 & 139132 & 16002 & 320446 \\
\hline
\end{tabular}


Table 14 Disposition of Current Retrievable TRU Waste

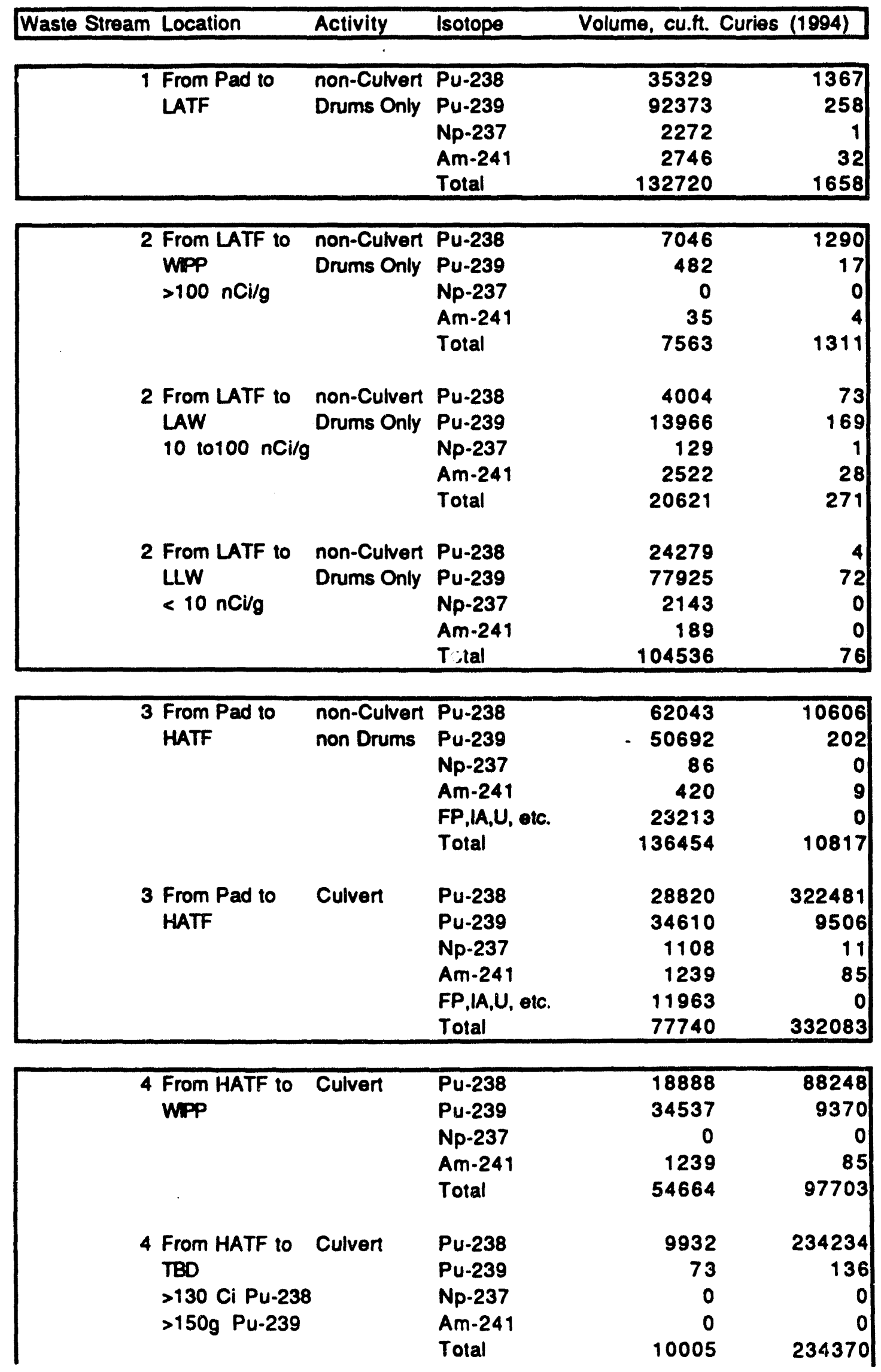


Table 14 Disposition of Current Retrievable TRU Waste

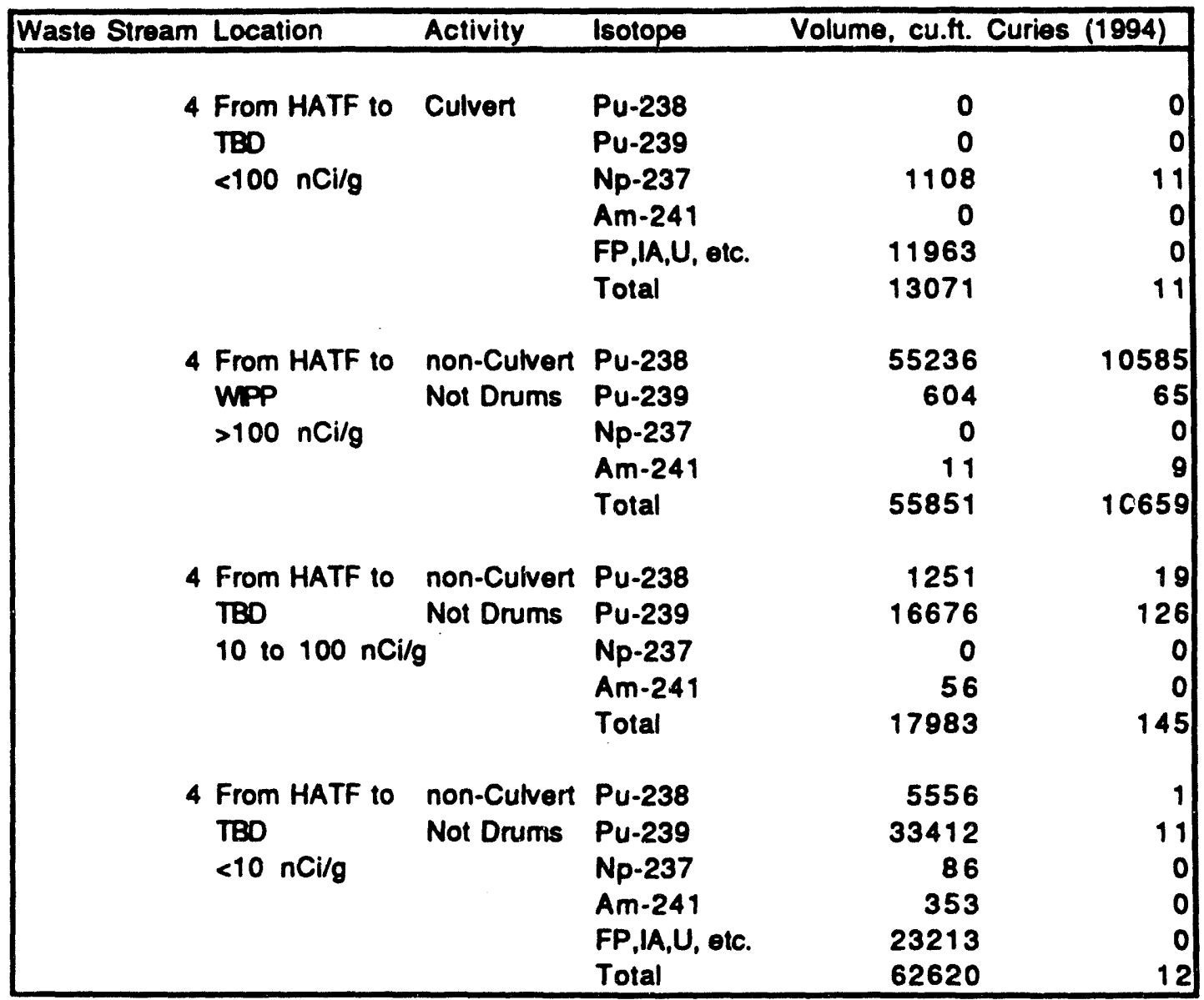

Inventory based on COBRA records of $99.6 \%$ of non-Culvert and $98.6 \%$ of Culvert records before mid-1992.

Might be considered all mixed waste because TRU waste that is unmixed (that generated since 1988 ) is less than 10,000 cubic feet.

This waste is currently considered an ER concem in the SW Strategic Plan

\begin{tabular}{|llllrr|}
\hline Waste Stream & Location & Activity & Isotope & Volume, cu.ft. Curies (1994) \\
Unaddressed & Mound \& LANL & Culvert & Pu-238 & 10315 & 214000 \\
Unaddressed & SRS & Pours & Pu-238 & 1611 & 455 \\
Unaddressed & SFS & Pours & Pu-239 & 9202 & 40 \\
Unaddressed & SRS & Pours & Np-237 & 294 & 0 \\
Unaddressed & SFS & Pours & Am-241 & 150 & 1 \\
Unaddressed & SRTC & Culvert & Cm-244 & 12643 & 15485 \\
Unaddressed & SRTC & non-Culvert & Cm-244 & 1198 & 305 \\
Unaddressed & SRTC & Pours & Cm-244 & 15892 & 1644 \\
Unaddressed & SRTC & Culvert & Cf-252 & 8788 & 0 \\
Unaddressed & SRTC & non-Culvert Cf-252 & 1360 & 0 \\
Unaddressed & SRTC & Pour & Cf-252 & 739 & 0 \\
& & & Total & 62192 & 231930 \\
\hline
\end{tabular}




\section{Figure 1 Current Transuranic Solid Waste Inventory Disposition}

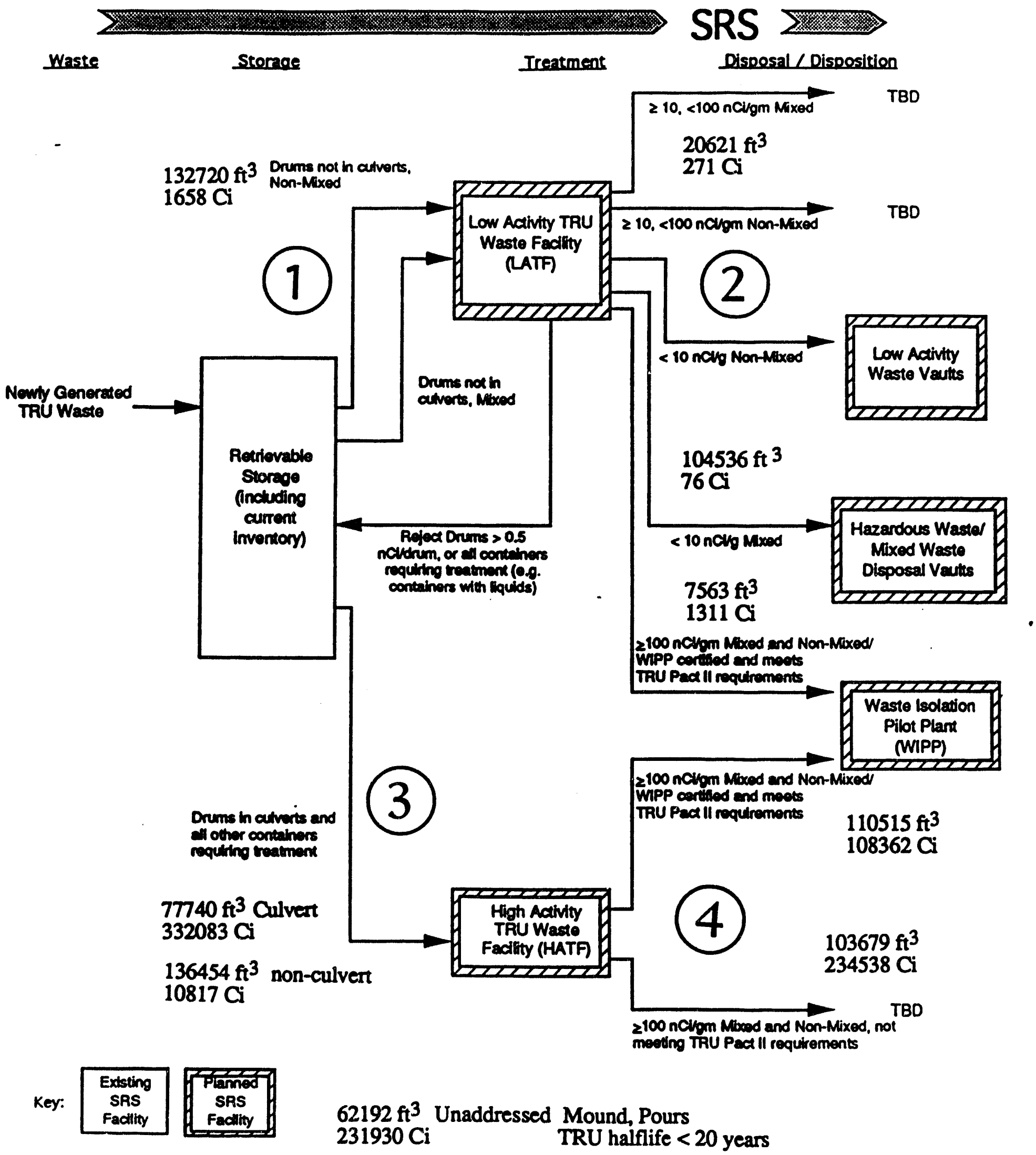


Figure 2 Projected Alpha Waste Generation

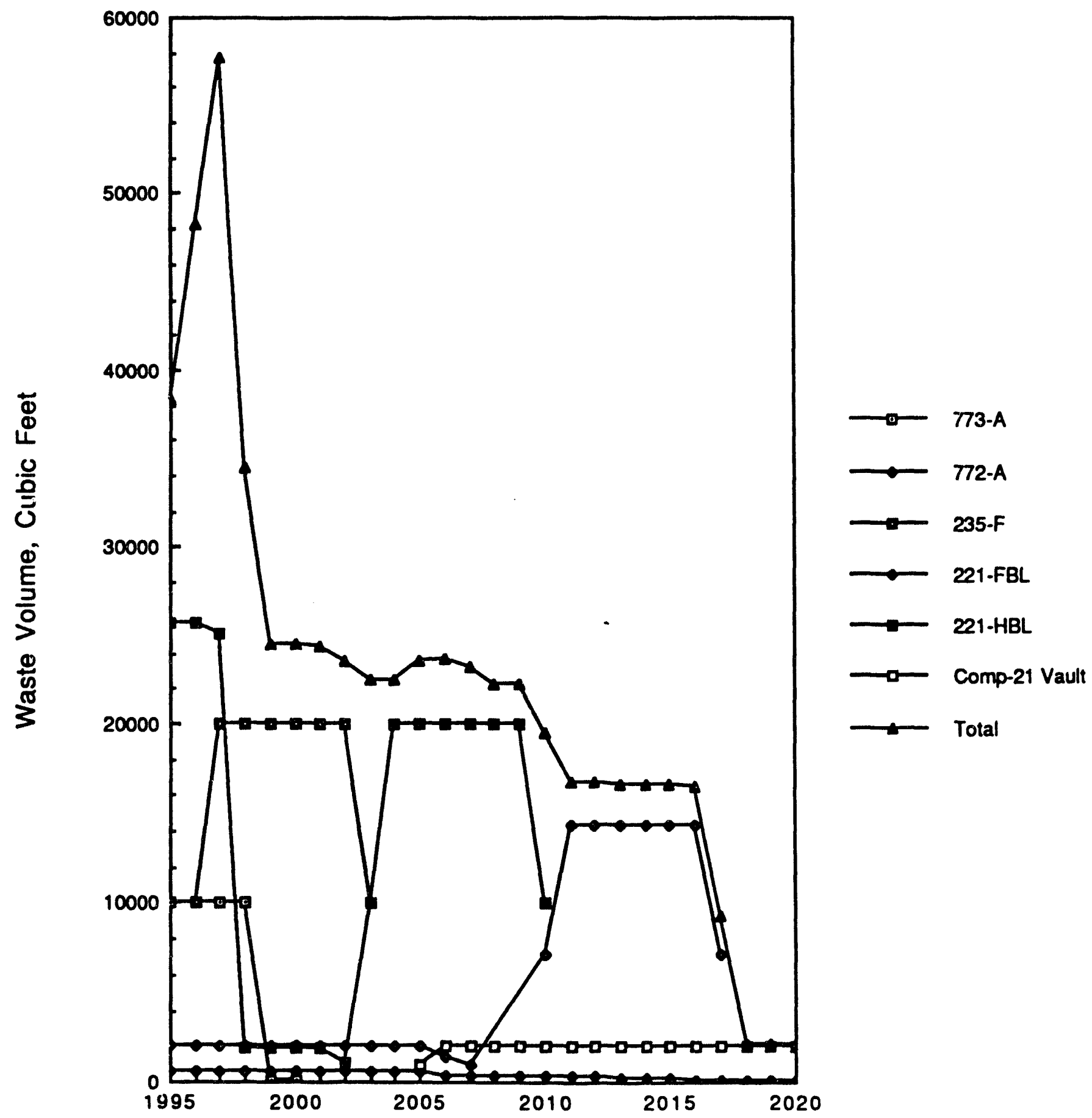

Calendar Year 
Figure 3 Current Retrievable TRU Waste Decay

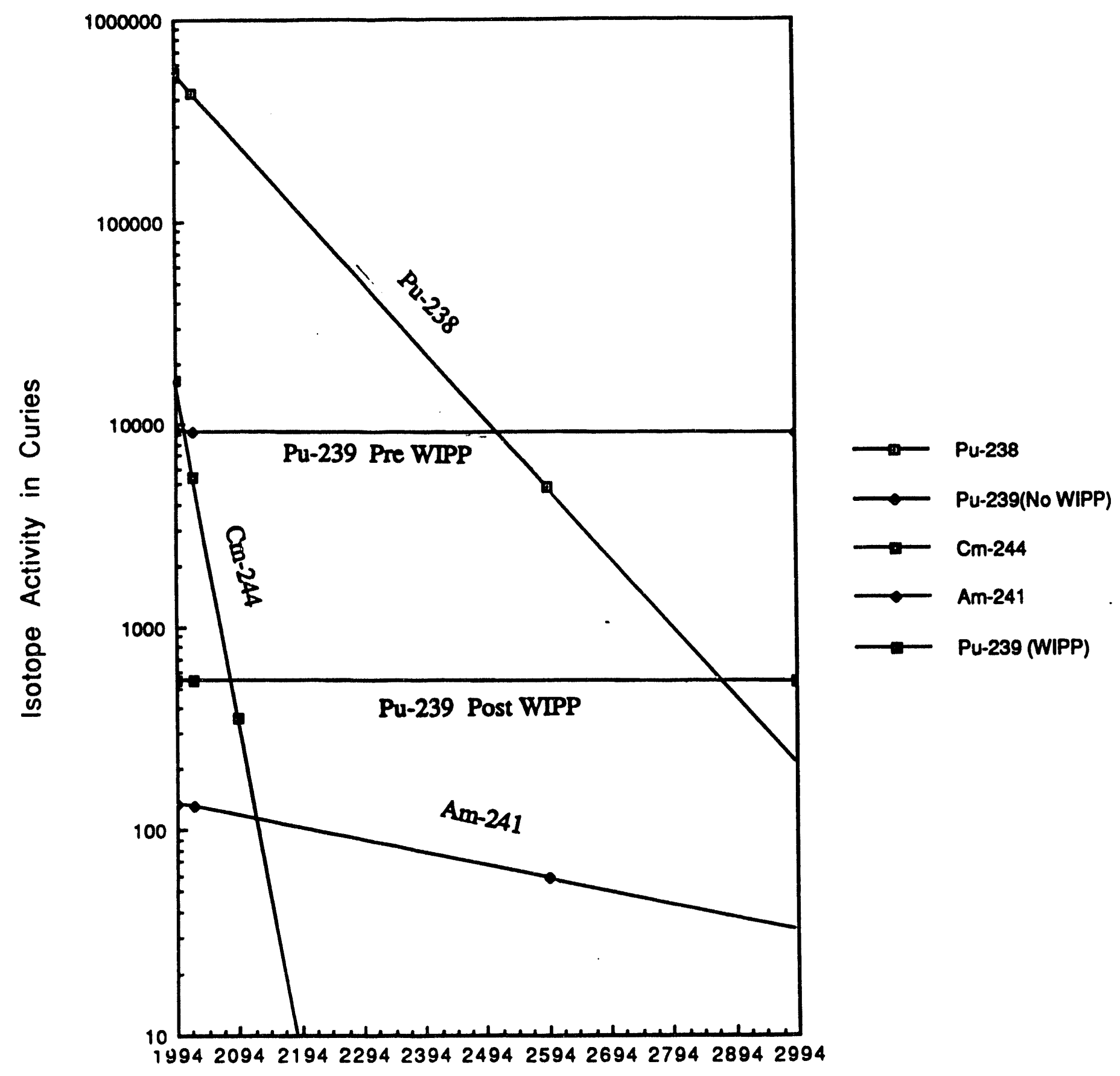

Calendar Year 

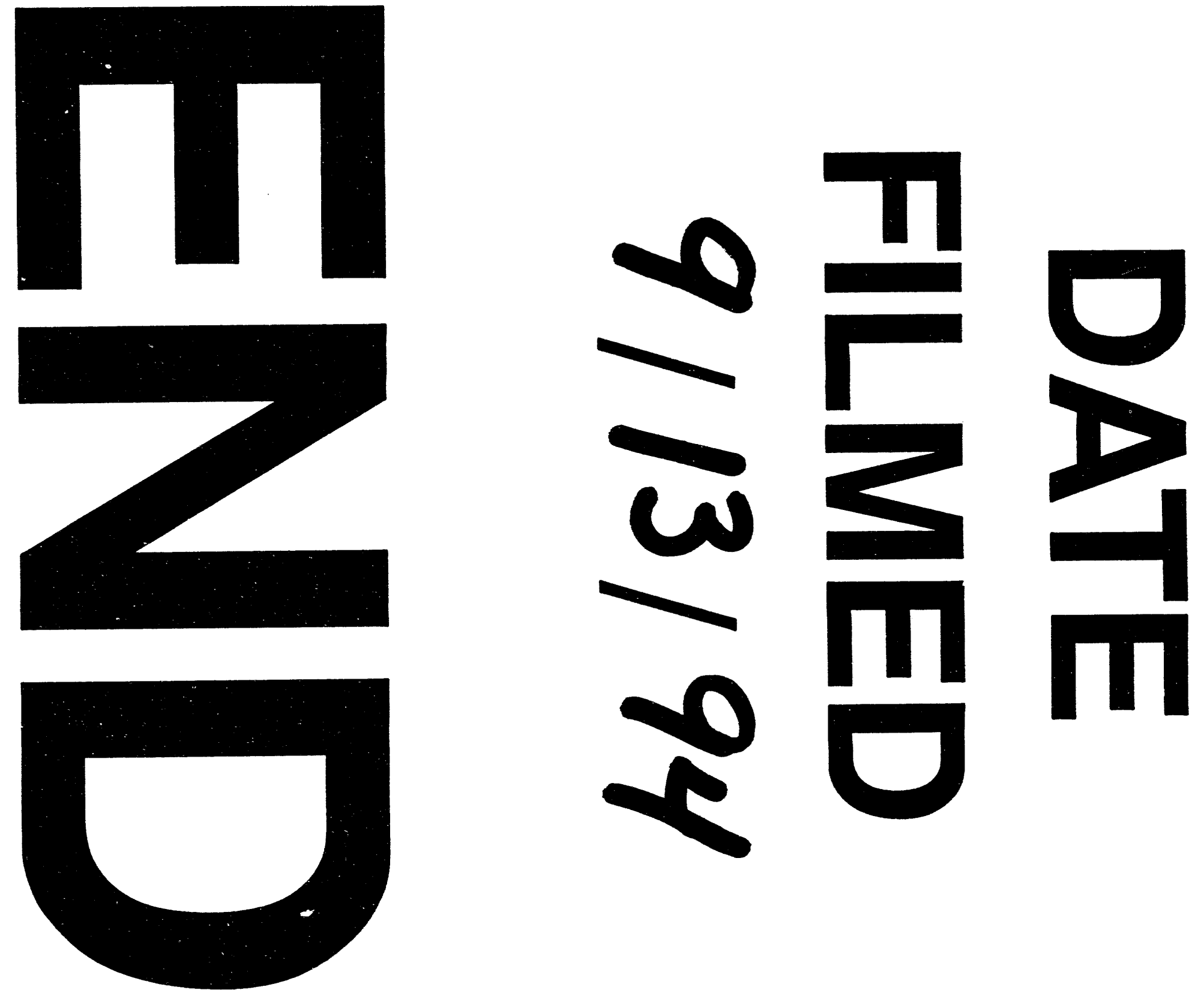
